\title{
Iconografía funeraria gótica en Castilla y León (siglos XIII y XIV)
}

Ángela Franco Mata

RESUMEN. En el presente artículo se analizan los diversos programas iconográficos que predominan en Castilla y León, en los que se pone de manifiesto la clase social a que el finado pertenece. Mientras los sepulcros pertenecientes al clero ostentan programas de carácter religioso, los de nobles y caballeros enfatizan su estatus social en el marco de las honras fúnebres como espectáculo y su evolución hacia la individualidad. También se analiza la disposición de caballeros con las piernas cruzadas y el denominado lit de parade, el lecho mortuorio sobre el que dispone al difunto para exposición pública.

Palabras clave: Gótico, Castilla y León, iconografía funeraria, siglos XIII y XIV.

ABSTRACT. This article analyses the iconographic programs most widely employed in Castille and Leon, in which the social position of the deceased is clearly stated. Whilst the tombs of ecclesiastics illustrate religious iconographic programs, those of knights and members of the nobility tend to emphasize their social status, through the representation of scenes of their burial and exequies, and the tendency towards an increasingly individualized character. The tomb type that shows the effigy of the deceased knight crossing his legs is also studied in this article, as well as the type known as 'lit de parade' with the representation of the bed where the body of the defunct was laid out for public display.

Key Words: Gothic, Castilla-León, Funerary iconography, XIIIth-XIVth century.

Castilla y León, unidas desde el reinado de Fernando III el Santo, conforman durante la Baja Edad Media una región que fundamenta en gran medida el devenir histórico del país. Los ejércitos reales avanzan progresivamente en la reconquista de los territorios ocupados por los árabes, hasta lograr expulsarlos durante el reinado de los Reyes Católicos. El arte funerario es variado y creativo, correspondiendo a la realeza, nobleza y clero la ilustración artística de los contenedores de los restos mortales para el reposo eterno de sus miembros. A conceptos aportados desde el arte foráneo se suman creaciones de talleres surgidos en algunas de las provincias, que gozaron de especial éxito. El siglo XIII está en la órbita de Francia, sobre todo en las provincias que configuran actualmente la comunidad de Castilla y León, es decir, la antigua Castilla la Vieja, y sus áreas de influencia, con tentáculos hacia las regiones limítrofes e incluso hasta Andalucía. Como en la arquitectura y escultura monumental de las catedrales de Burgos y León, llegan influencias de variados centros del vecino país. La clara dependencia estilística de la portada del Sarmental de la catedral burgalesa del Beau Dieu de Amiens, amén de otros elementos, se evidencia en varios 
sepulcros palentinos, hasta el punto que se ha propuesto la actividad de un escultor extranjero llegado a través del Camino de Peregrinación, o un escultor hispánico formado en los talleres de Burgos. El "panteón episcopal" leonés representa un punto de referencia en la segunda mitad del siglo XIII, por su extraordinaria creatividad y sentido de asimilación de elementos procedentes de Reims, Bourges y catedrales del sur de Francia. Aportaciones ideológicas, como la referencia a la herejía albigense y la idea del purgatorio, se evidencian respectivamente en los sepulcros de D. Rodrigo II Álvarez y de D. Martín Rodríguez (figs. 1, 3). Convenciones formales de este último serán adoptadas en sepulcros de otras provincias, como Salamanca y Ávila.

El siglo XIV, por su parte, que en la citada región sigue apegado a conceptos iconográficos del siglo anterior, introduce novedades vinculadas con la idea de la individualidad, que se pone de manifiesto en los monumentos funerarios y eventualmente explicitada a través de la documentación. Este siglo es particularmente interesante en el área toledana por la asimilación de conceptos llegados de Italia, de la mano de dos personajes del alto clero, el cardenal Gil Álvarez de Albornoz y el arzobispo Don Pedro Tenorio. Ambos se hacen construir sus sepulcros por el taller de Ferrand Gonzalez, del que conocemos bastante documentación. Plasma en los monumentos aspectos decorativos y conceptuales, algunos de ellos, como la iconografía de las Virtudes, derivan de la genial creación de Giovanni Pisano, que gozó de enorme predicamento entre sus discípulos Tino di Camaíno y Giovanni di Balduccio. El concepto de las Virtudes, sin embargo, es consignado en el Setenario con relación a Fernando III el santo. En las leyes II a IX, especialmente en la $\mathrm{V}$, se habla de las siete virtudes con que Dios lo adornó, las teologales -fe, esperanza y caridad- y las cardinales -justicia, mesura, nobleza y fortaleza-.
El protagonista del evento y del monumento funerario erigido para guardar sus restos y para memoria de la posteridad es el yacente ${ }^{1}$. Sin embargo, para una correcta comprensión de aquél debe de efectuarse el estudio del sepulcro en su conjunto. Los programas iconográficos desarrollados en los frentes, tres si es adosado y cuatro si es exento, y en el fondo del lucillo cuando se trata de este tipo de sepulcro, están organizados en función del propio finado, por más que se atengan frecuentemente a esquemas preestablecidos, adoptados de monumentos de especial relevancia como el del infante D. Felipe (figs. 8-9), levantisco hermano de Alfonso X, enterrado en la iglesia del convento templario de Villalcázar de Sirga y su esposa Inés Téllez Girón $^{2}$ (fig. 8, 10). En el siglo XIII conviven ideas religiosas derivadas del mundo románico -la Maiestas Domini y el Tetramorfos y el Agnus Dei- y temática evangélica, con la exaltación de la estirpe social por medio de la representación de cortejos fúnebres de gran aparato, paradigma de los cuales son los sepulcros antedichos. Por su parte, el siglo XIV introduce ciertos elementos destinados a personalizar la identidad del propio personaje, lo que supone un avance en cuanto a la especificación del individuo dentro del grupo social al que pertenece. Resulta sintomático el hecho de que los programas representados en los frentes de los sarcófagos van de acuerdo

\footnotetext{
1 "¿Dejar a los muertos enterrar a sus muertos?”. El difunto entre el aquí y el más allá en España y en Francia (ss. XI-XV), organizado por la Casa de Velázquez y la Universidad Autónoma de Madrid, 9-10 de diciembre de 1999, 10 de diciembre, coord. I. BANGO TORBISO y X. DECTOR.

${ }^{2}$ F. MENÉNDEZ PIDAL me expresó oralmente dicho aserto, que ya había sido publicado hacía muchos años por M. BALLESTEROS Y BERETTA, aserto que recogí en recensión a J. YARZA LUACES, Formas artísticas de lo imaginario, Barcelona, 1987 Boletín de la Asociación Española de Archiveros, Bibliotecarios, Museólogos y Documentalistas (ANABAD), XXXVIII (1988) pp. 304-305. El error fue arrastrado desde el siglo XIX.
} 
con la clase social a la que el difunto pertenece. Los miembros del clero prefieren obviamente la temática religiosa. Los nobles, en cambio, auténticos adelantados del renacimiento, desean poner de manifiesto la importancia de la estirpe y en consecuencia magnificar el duelo a través de la pompa y boato de la celebración de las exequias.

El monumento funerario con la propia figura yacente experimenta un proceso evolutivo desde el punto de vista estilístico y formal que explicita la evolución de las sucesivas modas imperantes en el área geográfica en análisis, así como la de influencia. El siglo XIII es especialmente rico en la catedral de León en el campo de la escultura funeraria referida al alto clero, poniéndose de manifiesto las relaciones artísticas con otros países, fundamentalmente Francia, para dejar paso luego al caput Castellae, Burgos, cuya riqueza, sobre todo en el siglo $\mathrm{XV}$, se debe en gran parte a la intensa actividad económica con los países del norte de Europa, fundamentalmente Flandes. La realeza y la nobleza son otros dos de los pilares sociales que contribuyen al desarrollo artístico. De aquí fluirán convenciones iconográficas y estilísticas, adoptadas en el arte funerario de las regiones limítrofes, sobre todo norteñas como Galicia, Asturias, Cantabria y Álava fundamentalmente. Con más retraso penetran fórmulas castellanas en las tierras conquistadas de Andalucía.

La imagen del yacente en la época gótica, que tiene su génesis en siglos anteriores, como han analizado diversos investigadores, E. Panofsky ${ }^{3}$, J. Beckwith ${ }^{4}$ y K.

\footnotetext{
${ }^{3}$ E. PANOFSKY, Tomb Sculpture. Its Changing Aspects Ancient Egypt to Bernini, Londres, 1964, reed. Nueva York, 1992.

${ }^{4}$ J. BeCKWITH, El arte de la Alta Edad Media. Carolingio. Otónico. Románico, versión castellana del original inglés, Barcelona, 1995. Este autor considera que la más antigua efigie sepulcral existente en Occidente es la figura en bronce del sarcófago de Rodolfo, rey de
}

Bauch ${ }^{5}$ entre otros, adquiere un amplísimo desarrollo durante los siglos comprendidos entre el XIII y el XV. Prologado en nuestro país por algunos ejemplos románicos ${ }^{6}$, entre ellos el de la Magdalena de Zamora, para el que recientemente se ha propuesto su identificación con doña Urraca, esposa del rey Alfonso IX ${ }^{7}$, alcanzará una gran importancia durante los dos siglos subsiguientes.

Aunque constituya un tópico, el yacente es el protagonista en el monumento funerario, y a él están supeditados todos los elementos del mismo, desde el sarcófago que contiene sus restos, los animales sobre los que monta, hasta la composición arquitectónica y los programas iconográficos, más o menos variados, cuya finalidad salvífica constituye el fundamento teológico, directamente vinculado a la liturgia. Sin este extremo, no sólo no se entiende el monumento funerario, sino que carece de sentido su ejecución. El desaparecido gisant del obispo Gebhart de Constanza, muerto en el 996, y enterrado en la abacial de San Pedro

-

Suabia (+ 1080), en la catedral de Merseburg, (p. 174, fig. 164).

${ }^{5}$ K. BAUCH, Das mittelalterliche Grabbild. Figürliche Grabmäler des 11. Bis 15 Jahrhunderts in Europa, Berlín/Nueva York, 1976.

${ }^{6}$ S. de SILVA Y VERÁSTEGUI, "La escultura funeraria en el románico español", Hispania Cristiana. Estudios en honor del Prof. Dr. José Orlandis Rovira en su septuagésimo aniversario, 1988, pp. 323-350.

${ }^{7}$ M. RuIz MALDONADO, “Dos obras maestras del románico de transición: La portada del Obispo y el sepulcro de la Magdalena", Stvdia Zamorensia Anejos, I, 1988, pp. 33-59; R. SÁNCHEZ AMEIJEIRAS, "La memoria perdida de un rey victorioso: La Fiesta del Triunfo de la Santa Cruz y los sepulcros medievales de Alfonso VIII en Las Huelgas"/"A Victorious King's lost memory: The Feast of the Triumph of the Holy Cross and Alfonso VIII's medieval tombs at Las Huelgas", Grabkunst und Sepulkralkultur in Spanien und Portugal/Arte fúnebre y cultura sepulcral en España y Portugal/Arte fúnebre e cultura sepulcral em Espanha e Portugal, Internationales Kolloquium der Carl Justi-Vereiningung und des Fachgebiets Kunstgeschichte der TU Dresden, Dresden, 16.19. März 2003, (Resúmenes), Dresde, 2003, pp. 50-52. 
y San Gregorio, aparece directamente relacionado con la celebración de la misa, como lo ponen de manifiesto los celebrantes en torno ${ }^{8}$. Piénsese que todavía actualmente se sigue celebrando una misa solemne de $R e-$ quiem anualmente el primer día después del Domingo in Albis, por el eterno descanso del monarca Ordoño II en la catedral de León, donde se dispone un túmulo con corona y cetro reales encima rodeado de ocho hacheros con cirios. Su monumento sepulcral gótico en la parte posterior de la capilla mayor del templo, está dotado de un profundo sentido político, aunque de carácter testimonial, por cuanto León y Castilla se unen durante el reinado de Fernando III el Santo. Obrado a fines del siglo XIII, fue ampliado en el XV. En el presente contexto interesa destacar algunos aspectos, sobre los que yo he incidido recientemente ${ }^{9}$. Se trata de la doble estatua, la yacente, reaprovechada indudablemente de otra de carácter monumental, como se echa de ver en los ojos, que en origen estaban abiertos y actualmente cerrados, y otra de pie, que en mi opinión fue trasladada de su lugar cuando se efectuaron las ampliaciones. Deriva dicha modalidad iconográfica de Francia, donde aparece la doble imagen de Clotario I y Sigeberto en la cripta de Saint-Médardde-Soissons y en los sepulcros de Juan y Blanca de Francia, realizados en metales limosinos. Son sin embargo, raros los ejemplos en el vecino país ${ }^{10}$. La imagen yacente del rey leonés deriva de cánones franceses.

\footnotetext{
-

${ }^{8}$ A. ERLANDE-BRANDENBURG, Le Roi est mort. Étude sur les funerailles, les sepultures et les tombeaux des rois de France jusqu'à la fin du XIIIe siècle, Ginebra/París, 1975, p. 110.

9 Á. FRANCO MATA, Escultura gótica en León y provincia (1230-1530), León 1998, pp. 394-401; Boto Varela, Gerardo, "El poder regio en la catedral de León: imagen y memoria", La catedral de León en la Edad Media. Congreso Internacional, León, 7-11 Abril, 2003 (en prensa).

${ }^{10}$ A. ERLANDE-BRANDENBURG, Le Roi est mort..., cit., p. 119.
}

Su esbeltez y el continente intemporal evocan la elegancia de los soberanos de Francia sepultados en Saint-Denis. De rostro joven e imberbe, se toca con corona y va peinado a la francesa con melena rematada hacia fuera, viste túnica y capa y sujeta el globo ${ }^{11}$. $\mathrm{Si}$ en origen predominan los conceptos de índole religiosa -Transfiguración y Crucifixión-, en las adiciones posteriores se enfatiza la figura del monarca con un ideario político vinculado a la reconquista y su carácter esperanzador en el marco escatológico $^{12}$.

A diferencia de este yacente, el panteón real compostelano adopta para los yacentes de los personajes allí sepultados fórmulas derivadas del arte de Maestro Mateo, lo que resulta muy explicable. Las yacentes atribuidas justamente por S. Moralejo a Alfonso IX (+ 1230), su hijo el infante don Fernando, y Fernando $\mathrm{II}^{13}$, proceden de los cánones creados por el genial artista del Pórtico de la Gloria, como ecos de su magistral creación. Tal vez haya que entender dentro de cánones compostelanos la disposición de las figuras en actitud durmiente, vueltos al espectador y llevándose con una mano el manto al rostro, disposición que el citado investigador les confiere como primicia iconográfica. Los ejemplares conocidos de este tipo en Galicia, Salamanca y Portugal, parecen remitir todos al modelo compostelano, con las posibles excepciones de Fernán Sánchez de Castro (+ 1275), hijo

\footnotetext{
${ }^{11}$ Para los sepulcros reales hispánicos vid. R. DEL ARCO, Sepulcros de la Casa Real de Castilla, Madrid; 1954; El Panteón Real de las Huelgas de Burgos. Los enterramientos de los Reyes de León y de Castilla, Valladolid, 1988, además de la bibliografía citada a lo largo de este trabajo.

12 Á FRANCO MATA, Escultura gótica en León y provincia..., cit. pp. 394-401.

${ }^{13}$ S. MORAlejo Álvarez, “¿Raimundo de Borgoña (+ 1107) o Fernando Alfonso (+ 1214)? Un episodio olvidado en la historia del Panteón Real compostelano", Galicia en la Edad Media, Sociedad Española de Estudios Medievales, 1990, pp. 161-179.
} 
bastardo de Jaime I de Aragón, en la ermita de San Salvador de Selgua y un fragmento tenido por francés en el Fogg Museum de Harvard $^{14}$. El yacente de la Catedral Vieja de Salamanca perteneciente al arcediano Garci López ${ }^{15}$ constituye un pálido reflejo de los modelos, pues es de calidad sensiblemente inferior. Ecos compostelanos se dejan sentir en Portugal, uno en el convento de Pombeiro, de fines del siglo XIII o comienzos del XIV ${ }^{16}$, y otro en el Museo Arqueológico do Carmo, de Lisboa ${ }^{17}$.

La representación del yacente del siglo XIII se caracteriza por su idealización; la imagen es convencional y el muerto reposa con gesto sereno y tranquilo a la espera de la resurrección, a veces en actitud sonriente. El difunto no tiene su edad real, es joven y feliz. Es representado como si estuviera vivo, pues el Cristianismo no cree más que en la vida. El artista muestra la muerte tal cual es en el pensamiento de Dios, y el muerto es figurado vivo y tal como será el gran día. Los yacentes aparecen frecuentemente con los ojos abiertos, dado que no son verdaderos muertos, sino que están vivos no sobre la tierra, sino en el más allá. El difunto despierta a la otra vida y por ello tiene los ojos abiertos a la luz perpetua, ya que la Iglesia le desea el descanso y la luz.

\footnotetext{
${ }^{14}$ S. Moralejo Álvarez,. “¿Raimundo de Borgoña" , cit. p. 168, nota 27.

${ }^{15}$ M. RUIZ MALDONADO, Margarita “El sepulcro del arcediano Garci López. Catedral Vieja de Salamanca", en Estudios de Arte. Homenaje al Profesor Martín González, Valladolid, 1995, pp. 433-437. Esta autora considera que está más relacionado con el yacente del arcediano de Ledesma, Garci López.

${ }^{16}$ S. Moralejo Álvarez, “¿Raimundo de Borgoña... " cit. p. 168 nota 27. Margarita M. RuIZ MALDONADO duda entre Joâo Gil de Soverosa y Joâo Alfonso de Alburquerque, cfr. Id., "El sepulcro de Fernando Sanches Rodrigues y su significación en la escultura funeraria portuguesa del siglo XIV", Goya, 233 (1933), pp. 268-273, sobre todo p. 269.

${ }^{17}$ M. RUIZ MALDONADO, "El sepulcro del arcediano..." p. 436; Id. "El sepulcro de Fernando Sanches Rodríguez...", cit. pp. 268-273.
}

Esta modalidad convive con la de la figuración del difunto con los ojos cerrados, más frecuente a partir del siglo XIV, pero ambas conforman la plástica funeraria del siglo XIII. Aparece dormido, pues eso es la muerte, un sueño en espera de la resurrección para otra vida mejor. En el siglo XIV se impone la tendencia hacia el realismo, proclive a reflejar ciertos rasgos de individualidad en el rostro, idea presente en los programas iconográficos desarrollados en los frentes del sarcófago. Dicha convención viene motivada en cierta manera por la utilización de mascarillas. Contribuyó también el hecho de la prescripción por parte de los interesados de la estatua yacente "muy semejante a su figura". Incluso sabemos que algunos la mandaban realizar en vida. Ello justifica en mayor medida la tendencia hacia el retrato, pero no significa una representación fiel del mismo; más bien podría hablarse de un realismo idealizado, como ha propuesto algún autor ${ }^{18}$. En el siglo XIII, el yacente reposa sobre un cojín, que se eleva a dos en el siglo siguiente y eventualmente a tres, lo cual es privativo de personajes de alta categoría social, relacionada sobre todo con el clero. Sirva de ejemplo el sepulcro del obispo don Rodrigo Díaz (+ 1339) en la catedral Vieja de Salamanca ${ }^{19}$.

La disposición del yacente varía tanto desde el punto de vista cronológico como en relación con el estatus social. Los eclesiásticos suelen aparecer con el libro cerrado entre las manos. Sólo en casos excepcionales se muestra con un libro abierto, como

\footnotetext{
-

${ }^{18}$ Cfr. Ma J. GÓMEZ BÁRCENA, “El sepulcro gótico en la ciudad de Burgos en la crisis del siglo XIV", en $\mathrm{La}$ ciudad de Burgos. Actas del Congreso de Historia de Burgos MC Aniversario de la fundación de la ciudad de Burgos 884-1984, Burgos, 1985, pp. 863-881, sobre todo pp. 868-870.

${ }^{19}$ M. GÓMEZ Moreno, Catálogo Monumental de España. Provincia de Salamanca, Madrid, 1967, p. 120, fig. 58; J. Ma de AzCÁRATe, Arte gótico en España, Madrid, 1990, fig. en p. 312.
} 
es el caso del personaje enterrado en la iglesia de San Vicente de la Barquera (Cantabria), que se asemeja a ejemplares de personajes enterrados en la catedral de Lisboa. Excepcional es el arcipreste de Aguilar de Campoo Garci González, que presenta una peculiaridad de orden iconográfico y que podemos interpretarlo actualmente como un unicum: era portador del preceptivo cáliz. El sepulcro del arcipreste Garci González, en origen en el presbiterio de la colegiata de San Miguel, ha sido trasladado al centro de la capilla de los Pobres o del arcipreste del Fresno. Es exento y sus cuatro frentes están recorridos por las escenas de las exequias, incluido el cortejo y transporte del féretro, con la Crucifixión a la cabecera y un Juicio Final en el frente opuesto. Debía de tener especial devoción mariana, ya que una Virgen con Niño figura sobre el libro que sostiene entre las manos ${ }^{20}$. Durante la Edad Media era preceptivo que los sacerdotes tanto obispos, como abades y presbíteros fueran enterrados con el cáliz, realizado en plomo, estaño, peltre (aleación de estaño y plomo) e incluso de cera ${ }^{21}$, como era el caso. Dicho vaso sagrado fue hallado en el momento del traslado del sepulcro a principios del siglo pasado, tras la urna, junto con clavos, trozos de tisú carmesí y de oro y fragmentos de madera de roble del féretro. La costumbre pervive al menos hasta el siglo $\mathrm{XV}$, como se evidencia a través de varios cálices conservados en diversos museos, como el conjunto también palentino -

\footnotetext{
${ }^{20}$ J. L. HERNANDO GARRIDO, “Algunas notas sobre los sepulcros de Aguilar de Campoo: un grupo escueto palentino de 1300", Boletín del Museo e Instituto "Camón Aznar”, 37, 1989, pp. 87-109; C.J. ARA GIL, “Un grupo de sepulcros palentinos del siglo XIII: los primeros talleres de Carrión de los Condes, Pedro Pintor y Roi Martínez de Bureva", II Curso de Cultura Medieval Alfonso VIII y su época, Aguilar de Campoo, 1-6 octubre 1990, Aguilar, 1992, pp. 21-52.

21 Á. Rivera De LAS HerAs, "El esplendor de la liturgia", catálogo exposición La Platería en la época de los Austrias Mayores en Castilla y León, Valladolid, 1999, pp. 19-55, sobre todo p. 33.
}

Pago de Santa María, Renedo del Montedel Museo Arqueológico Nacional, junto con la patena y las dos vinajeras ${ }^{22}$. Eventualmente se esculpía con el cáliz la figura yacente, como el Dr. Grado en la catedral de Zamora ${ }^{23}$.

La imagen del yacente en el mundo gótico castellano presenta una serie de elementos que la incardinan con lo europeo y que conviven a su vez con otras notas de clara raigambre local, lo cual les presta un carácter muy peculiar. No se han analizado para nuestro país cuestiones relativas a la construcción del monumento funerario, que en Francia han sido tratadas por A. Kleinclauz $^{24}$. En numerosos sepulcros castellanos se insiste en el carácter narrativo de la celebración de las exequias, apenas desarrollado o ausente en otros países. En el siglo XIII varias novedades aportan sobre todo las altas jerarquías eclesiásticas, a cuyo cargo se hallaban las construcciones de las catedrales. No se entendería el monumento sepulcral con yacente dormido del obispo D. Martín Fernández (+1289) en la catedral de León, sin tener en cuenta las obras de los maestros franceses, como en este caso el Maestro de la Coronería, en Burgos. León, sin embargo, adopta ya antes estilemas venidos del vecino país, en el sepulcro del obispo D. Rodrigo II Álvarez (+ 1232), imitado puntualmente en el monumento de

\footnotetext{
${ }^{22}$ N. inv. 57088-57091.

${ }^{23}$ J. YARZA LUACES, "La portada occidental de la colegiata de Toro y el sepulcro del doctor Grado, dos obras significativas del gótico zamorano", Stvdia Zamorensia (Anejos), Zamora/Salamanca, 1988, pp. 117152; G. T. TEJEDOR MiCó, "Escultura funeraria. El sepulcro del doctor Grado en la catedral de Zamora", Boletín del Museo e Instituto "Camón Aznar", LIII (1993), pp. 29-70.

24 A. KLeinclauZ, “L'art funéraire de la Bourgogne au Moyen Age", Gazette des Beaux-Arts, XXVI, (1902), pp. 443-458 y XXVII, pp. 299-320, cit. por D. AleXANDRe-BIDON, La mort au Moyen Age XIIIeXVIe siècle, París, 1998, pp. 209-214, donde plantea varios interrogantes.
} 
Don Martín Rodríguez (+ 1242) y en el de don Diego Ramírez de Guzmán (13441354). Con su monumento sepulcral se introduce en España el tipo denominado en$\mathrm{feu}$, con prototipos conocidos en Francia, como el desaparecido monumento de Arnould de Chartres $(+1031)$ y el de Henry de France $(+1171)$, del que pervive su transformación en la Porte Romane en la catedral de Reims ${ }^{25}$ (fig. 2). El yacente va ataviado de acuerdo con un modelo proveniente de la escultura chartriana, en las figuras de talante intemporal de personajes dispuestos en las portadas del crucero sur.

El pastor de la diócesis elegía evidentemente como lugar de reposo definitivo el más destacado de la iglesia, el coro. Así lo determina el gran constructor de la catedral de León, en su testamento: que fagan sepultar nuestro cuerpo en la sepoltura que fezimos fazer en el coro de nuestra iglesia ${ }^{26}$. Dicho emplazamiento se justificaba por ser donde los canónigos oraban comunitariamente. De hecho, ya antes había tomado la misma determinación el obispo D. Mauricio, en la catedral de Burgos. Esta razón movió asimismo a fundadores y benefactores de monasterios a elegir dicha ubicación. Los monumentos exentos constituyen un sistema de prestigiar a los prelados, como el citado burgalés, que ordenó realizar su efigie funeraria en la refinada obra de Limoges, sistema adoptado frecuentemente en Francia, e Inglaterra ${ }^{27}$. Pero también los obispos

25 R. SÁNCHEZ AMEIJEIRAS, "Monumenta et memoriae: the thirteenth-century Episcopal pantheon of León cathedral", Memory and the Medieval Tomb, ed. E. Valdez del Alamo con C. Stamatis Pendergast, Cambridge, 2000, 269-299. Manejé el texto inédito amablemente cedido por la autora, a quien expreso mi gratitud

${ }^{26}$ Á FRANCO MATA, Escultura gótica en León y provincia..., cit. p. 393.

${ }^{27}$ M. M. GAUTHIER, "Naissance du defunt à la vie eternelle: les tombeaux d'émaux de Limoges aux XIIe et XIIIe siècles", en La figuration des morts dans la se hacían enterrar en monumentos adosados, mirando al altar, fórmula que aunque es considerada canónica, en la práctica no sucedía siempre. Los deanes, arcedianos y otras autoridades inferiores eran generalmente sepultados en los claustros y capillas. Por su parte, los nobles se hacían acreedores de su última morada en las iglesias de los monasterios, gracias a que frecuentemente eran fundaciones suyas. También se adopta la doble modalidad de sepulcros exentos, como los fundadores del monasterio de Gradefes, o adosados, como en el monasterio de Sandoval, ambos en la provincia de León.

La escultura funeraria de la catedral de León gozó de gran apogeo durante el siglo XIII. Sus relaciones internacionales a la vez que su creatividad se ponen de manifiesto a través de varios monumentos, prologados por el lucillo o enfeu de D. Rodrigo. Constituye un alegato contra la herejía albigense, que hacía estragos por toda Europa y había penetrado en León vía camino de Santiago. Procedente de la catedral románi$\mathrm{ca}$, fue realizado en dos etapas diferentes, a la primera de las cuales corresponden el yacente, los relieves del fondo, excavado en el muro y rematado exteriormente por un arco de medio punto, y el frente de la yacija, así como el toro de San Lucas y el león de San Marcos. Se incluye la novedosa escena de la celebración de las exequias, de gran predicamento en la escultura funeraria posterior en Castilla ${ }^{28}$. El oficiante, como correspondía a la dignidad del finado, es un obispo junto al que se sitúan los acólitos portadores del libro, naveta, incensario, cirios y la cruz. Contrasta con este conjunto

\footnotetext{
chretienté médiévale jusqu'à la fin du premier quart du XIVe siècle, Fontevraud, 1988, pp. 97-116.

${ }^{28} \mathrm{M}^{\mathrm{a}} \mathrm{J}$. GÓMEZ BÁRCENA, “La Liturgia de los funerales y su Repercusión en la Escultura Gótica Funeraria en Castilla", La Idea y el Sentimiento de la Muerte en la Historia y en el Arte de la Edad Media, Santiago de Compostela, Universidad, 1988, pp. 31-50.
} 
el de fieles llorosos y plañideras que se mesan los cabellos, actitud proveniente de viejas costumbres paganas, denostada por la legislación de Alfonso X el Sabio. En el registro superior del fondo se dispone la Crucifixión, cuya modalidad se inscribe en un contexto propagandístico. El Crucificado es de cuatro clavos, número con el que se contrapone al de tres, aceptado por la secta, como advierte Lucas de Tuy. Dicho número es abolido de ahora en adelante. El alma del finado es conducida al paraíso por dos ángeles de acuerdo con la clásica fórmula de la elevatio animae. Dejando aparte otros elementos que vinculan el monumento con la erradicación de la herejía, conviene destacar la escena de la pitança de los aniversarios, una constante en la documentación medieval hispana, representada por medio de varios servidores del prelado que reparten alimentos entre los necesitados ${ }^{29}$ (fig. 3). El obispo, como primera autoridad de la diócesis, debía de dar ejemplo en la expresión de la caridad, concepto que se recoge en los testamentos, así el infante don Juan, hijo de Alfonso X ordena en 1319 que el día de su entierro se vistiese a mil pobres con "pellotes y sayas de sayal" y que a todos los asistentes a su sepelio se les diese de comer pan, carne y vino o pan, pescado y vino, dependiendo del día, de abstinencia o no. Muchos otros testamentos recogen mandas en este sentido ${ }^{30}$.

El programa iconográfico del sepulcro de D. Rodrigo será adoptado en el del

\footnotetext{
29 Á FRANCO MATA, Escultura gótica en León y provincia..., cit. pp. 384-388.

${ }^{30} \mathrm{M}^{\mathrm{a}} \mathrm{J}$. GÓMEZ BÁRCENA, La Liturgia de los Funerales..., cit. pp. 31-50; C. JARA GIL, “Un grupo de sepulcros palentinos del siglo XIII...", cit. pp. 21-52; R. SÁNCHEZ AMEIJEIRAS, "Un espectáculo urbano en la Castilla medieval: las honras fúnebres del caballero", El Rostro y el Discurso de la Fiesta, ed. M. NúÑEZ RODRÍGUEZ, Santiago de Compostela, 1994, pp. 141-157; Á

FRANCO MATA, Escultura gótica en León y provincia ..., cit., pp. 416-420; 442.
}

obispo D. Martín II Rodríguez -o Arias-, "el zamorano" (1239-1242) ${ }^{31}$, pero se introducen variantes que marcan diferencias conceptuales, algunas de las cuales serán plasmadas en otros monumentos sepulcrales de la región castellana. De la escultura monumental de la catedral hereda un elemento: Cristo bendiciendo, sobre la arquivolta exterior de la portada del Juicio Final se transporta al arco de enmarque del lucillo. Aunque responde a la misma conformación estructural que el monumento de D. Rodrigo, el sepulcro de D. Martín Rodríguez constituye un conjunto artístico de extraordinaria calidad y equilibrio, en el que se aprecia la consumación de una línea evolutiva por parte de un gran artista, que será adoptado en Ávila, aunque con resultados mediocres. Se han invertido los elementos de las escenas de las exequias y de la pitança de aniversarios. El conjunto con la evocación paradisíaca como un jardín por medio de vegetación está expresado con mano hábil y eficaz.

La vinculación de la iconografía y algunos conceptos abstractos con la idea del purgatorio han sido puestos de manifiesto por L. Morganti ${ }^{32}$ y más recientemente por C. García Álvarez ${ }^{33}$. Uno de los primeros testimonios de la importancia concedida a la celebración de la misa por los difuntos considerada como la forma más eficaz de impetrar la misericordia divina para abreviar así la permanencia de los seres queri-

-

31 J. YARZA LUACES, “Despesas fazen los ommes de muchas guisas en soterrar los muertos", Fragmentos, 2 (1985), pp. 4-19, recogido en Formas artísticas de lo imaginario, pp. 260-292.

32 L. MORGANTI, "La celebrazione degli 'anniversari' e l'affermazione del concetto di purgatorio nel XIII: il monumento di Martín II Rodríguez nella cattedrale di León e Lucas de Tuy", Arte medievale, X, (1996), pp. 99-122.

${ }^{33}$ C. García Álvarez, El Laberinto del alma. Una interpretación de las enjutas de las capillas absidales de la catedral de León, prólogo de Á. FRANCO MATA, León, Universidad, 2003, pp. 70-100. 
dos en el purgatorio es el documento del cardenal Pelayo Albanense datado en Perugia el 25 de enero de 1230, por el cual funda una capellanía en la catedral de León para la celebración perhenniter de una missa pro defunctis, por su alma y la de sus padres, y todos los fieles, para lo cual dona 300 áureos alfonsinos como renta para los encargados de la capilla. En la misma fecha el cardenal destina algunas propiedades al monasterio de Carvajal, cerca de León, para celebrar el propio aniversario ad perennem memoriam posterorum tres veces al año.

El obispo Martín Rodríguez contribuyó eficazmente a la normativa de la legislación capitular del siglo XIII y tras él su sucesor D. Martín III Fernández (1254-1289) (fig. 4), contribuciones que se dejan sentir en otras sedes episcopales entre ellas en la de Ávila. La iconografía del sepulcro del primero brinda una lectura incardinada con conceptos religiosos cuyo sentido era negado por la herejía albigense. En primer lugar, el Calvario y el grupo de la Virgen entronizada con el Niño reafirman por una parte el valor de la pasión real de Cristo, y de otra el valor de la intercesión de la Virgen como madre de Dios. Las exequias, misas, procesiones y cortejos fúnebres escandalizaban a los herejes. Como contrapartida, estas manifestaciones cultuales se imprimen en el arte funerario y adquieren especial relevancia las escenas de cortejos fúnebres, ceremonias de absolución y otras formas de recuerdo. En contra de la fatalidad de la predestinación propugnada por los albigenses, la preocupación caritativa se expresa por medio de los testamentos, a través de los cuales se dejan mandas ${ }^{34}$. Como en el monumento de don Rodrigo, se dedica el frente del sarcófago a plasmar la donación

${ }^{34}$ A. RUCQUOI, De la resignación al miedo: La Muerte en Castilla en el siglo XV, La idea y el Sentimiento de la Muerte en la Historia y en el Arte de la Edad Media, Santiago de Compostela, 1988, pp. 51-66. de pan a los pobres, que ha sido plasmada en el sepulcro abulense de don Hernando ${ }^{35}$. La negación de la idea del purgatorio y de la resurrección corporal traía consigo la carencia de valor de las indulgencias, sufragios e intercesión de los santos para la salvación de los difuntos. El arte cristiano, sobre todo en Francia y España, se levanta contra estas ideas por medio de la elevatio animae elevada al cielo por medio de ángeles y el tema de los dolientes, pleurants o plañideras, de amplia difusión en el arte gótico.

El sepulcro de don Hernando constituye un compendio de elementos del sepulcro de Martín Rodríguez, al tiempo que se hace palpable la ausencia del sentido de arquitectónico que anima el modelo. Carece del arco que enmarca el fondo del monumento leonés, reemplazado por un hueco de estructura paralelepipédica que acoge la figura del yacente y el relieve con la elevatio animae y las figuras de tres religiosos, un franciscano y dos dominicos, sustituto de la escena de las exequias. La elevatio está resuelta de forma un tanto original. El alma emerge de las nubes, de estructura oval y abigarrada, ayudada por dos ángeles arrodillados, herencia de la escultura monumental y de gran predicamento en el arte funerario. Los tres religiosos están inscritos en reducidos habitáculos rectangulares. Su presencia en este ámbito pone de relieve la importancia de las órdenes mendicantes, recientemente fundadas, en el papel de dispensadores de los últimos auxilios a los moribundos en progresiva sustitución de las órdenes monásticas.

La incidencia en la iconografía de los religiosos, monjes y frailes, en el marco funerario es lógica por su especial protago-

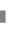

35 Á FRANCO MATA, "Escultura funeraria en León en el siglo XIII y su área de influencia", Arte d'Occidente. Temi e metodi. Studi in onore di Angiola Maria Romanini, Roma, 1999, I, pp. 527-535.
} 
nismo a la hora de la muerte como dispensadores de los últimos auxilios. El hábito de las órdenes mendicantes se hizo frecuente durante los siglos bajomedievales no sólo en nuestro país, sino también en el resto de Europa $^{36}$. En nuestro país adopta diferentes modalidades que estimo interesante poner de relieve. En los sepulcros de personajes pertenecientes al clero son acompañantes de los oficiantes de las exequias, como en los monumentos del clero secular. Papel más activo y destacado desempeñan en los funerales de miembros de la nobleza, fundadores de monasterios o poseedores de espacios o capillas funerarias adquiridas por ellos para su reposo definitivo. En el más o menos amplio desarrollo de la liturgia de funerales grupos de monjes pululan por las diversas escenas que tienen lugar desde la casa mortuoria hasta la deposición del cadáver en la tumba. Con la progresiva imposición de franciscanos y dominicos recae sobre éstos la preponderancia iconográfica, que adopta variadas formas.

No es fácil determinar quién impuso la moda, si tenemos en cuenta la cronología de determinados monumentos funerarios. De admitirse como de comienzos del siglo XIV el sepulcro de dama perteneciente a la familia Villalobos Girón Cisneros, sepultada en el monasterio de Bujedo (Burgos), actualmente en el Museo Arqueológico Nacional de Madrid, se situaría entre los primeros ejemplares de una dama ataviada con hábito franciscano ${ }^{37}$. Algunos monarcas se hicieron inhumar vestidos con el mismo atuendo, como es el caso de Sancho el Bravo. Este monarca, muerto de camino de regreso de una campaña en el reino de Granada, fue enterrado con humilde sayal franciscano, pero acompañado de sus

${ }^{36}$ D. AleXANDRE-BIDON, La mort au Moyen Age XIIIe-XVIe siècle, París, 1998, pp. 111-114.

${ }^{37}$ Á Franco Mata, Museo Arqueológico Nacional. Catálogo de la escultura gótica, (1980), 2 $2^{\mathrm{a}}$ ed., Madrid, 1993, p. 105. prendas de rey: corona, espada con su tahalí, acicates y envuelto en riquísima colcha de tapicería árabe ${ }^{38}$. Sancho IV y Enrique III dejan consignado su deseo de ser vestidos con el hábito de san Francisco. La Crónica de los Reyes de Castilla Fernando III, Alfonso X, Sancho IV, de Loaysa: "[Sancho IV] fue sepultado en la iglesia catedral de esta última ciudad [Toledo] en la misma iglesia que hacia tiempo había sido coronado y en su propia capilla en regio sepulcro habiendo tomado antes de morir el hábito de la orden del bienaventurado Francisco" ${ }^{39}$. La Crónica de Enrique III recoge: "Encomiendo mi alma a Dios Nuestro Señor que la crió e ha de salvar si la su merced fuere; e mando quel mi cuerpo sea enterrado en el hábito de San Francisco en la Iglesia de Santa María de Toledo Catedral" ${ }^{40}$. Enrique II y Catalina de Lancaster, por su parte, se hicieron enterrar con el hábito de santo Domingo, como la reina Beatriz de Portugal, inhumada en el convento de Sancti Spiritus de Toro. Doble imagen, como reina y como religiosa -en lit de parade- está plasmada en el monumento funerario con el acompañamiento de los santos más prestigiosos de la orden ${ }^{41}$. La nobleza también se acoge a estas prebendas espirituales. Sigue la pauta de esta disposición iconográfica Pedro Suárez de Toledo, muerto en la batalla de Troncoso en 1385, conservado en el Museo Marès de Barcelona. Está vestido con la armadura de caballero disimulada

${ }^{38} \mathrm{M}^{\mathrm{a}}$ E. Gómez MORENO, Manuel Gómez-Moreno Martínez, Madrid, 1995, p. 494. Para el sepulcro vid. M. M. NúÑEZ RODRÍGUEZ, "Iconografía de humildad: el yacente de Sancho IV", Boletín del Museo Arqueológico Nacional, 3 (1985), pp. 169-175.

${ }^{39}$ M. NÚÑEZ RODRÍGUEZ, "La Indumentaria como Símbolo en la iconografía Funeraria", La idea y el Sentimiento de la Muerte en la Historia y en el Arte de la Edad Media, Santiago de Compostela, 1988, pp. 9-19, sobre todo p. 12.

${ }^{40}$ M. NÚÑEZ RODRÍGUEZ, La indumentaria..., cit. p. 12.

41 M. RuIz MALDONADO, "El sepulcro de doña Beatriz de Portugal en Sancti Spiritus (Toro)", Goya, 237 (1993), pp. 142-148. 
bajo el hábito franciscano; el propio cordón enmarca los escudos del frente del sarcófa$\mathrm{go}^{42}$. El franciscanismo del caballero Fernán Pérez de Andrade $o$ Boo, fundador de San Francisco de Betanzos se manifiesta por medio de la disposición del sepulcro dominando la propia iglesia y el cordón franciscano sobre su atuendo de guerrero ${ }^{43}$.

En el frente de la yacija del obispo D. Hernando se dispone la escena de la distribución de panes y viandas entre los pobres, en la que ya Gómez Moreno ve el sufragio del difunto ${ }^{44}$. Aunque la conservación del relieve es deficiente, por efecto indudablemente de agresiones de manos bárbaras, la disposición de los personajes sigue puntualmente la del obispo don Martín; hasta

42 Á Franco MATA, "El sepulcro de don Pedro Suárez III (s. XIV) y el taller toledano de Ferrad Gonzalez", Boletín del Museo Arqueológico Nacional, 9, n. 1 y 2, 1991, pp. 87-100, donde aludo a los yacentes y atuendo de los distintos personajes de los sepulcros tallados en el taller de Ferrand González.

${ }^{43}$ La literatura sobre el sepulcro de este destacado personaje es muy amplia. Por ello consigno tan sólo M. NúÑEz RodríGUEZ, “El sepulcro de Fernan Pérez de Andrade en San Francisco de Betanzos como expresión de una individualidad y una época", Bracara Augusta, XXXV, (1981), separata, pp. 1-19; J. YARZA LUACES, “La capilla funeraria hispana en torno a 1400", La Idea y el Sentimiento de la Muerte en la Historia y en el Arte de la Edad Media, Santiago de Compostela, 1988, pp. 67-91; C. MANSO PORTO, "San Francisco de Betanzos. Catálogo de los temas profanos de caza y de los religiosos próximos a ellos, conservados en el interior de la iglesia", Anuario Brigantino, 10 (1987), pp. 121-126; C. MANSO PORTO, Arte gótico en Galicia: los dominicos, La Coruña, 1993, I, cap. IV y V; C. MANSO PORTO, “El mundo profano en la imaginería gótica de los conventos mendicantes gallegos: la caza", Boletín del Museo Arqueológico Nacional, XVIII, (2000), pp. 231-253.

${ }^{44}$ M. Gómez Moreno, Catálogo Monumental de la provincia de Ávila, edición revisada y preparada por Á. de la Morena Bartolomé y T. Pérez Higuera, Madrid/Ávila, 1983, I, p. 96, lám. 63; E. RUIZ AYÚCAR, Sepulcros artísticos de Ávila, 2a ed. corregida y aumentada, Ávila, 1985, pp. 75, 96; J. M. MARTíNEZ FRÍAS, "Ávila", España Gótica. Castilla y León/1, coord. S. ANDRÉS ORDAX, Madrid, 1989, p. 462. A. FRANCO MATA, "Escultura gótica en Ávila", Historia de Ávila, vol. III (en prensa) los dos mendigos portadores de bolsa con la concha venera de peregrinos jacobeos se repiten en sepulcro abulense. El sepulcro está emplazado en la capilla de San Nicolás, en el ámbito de la girola. El prelado, cuya identidad se pregona en una inscripción en caracteres góticos, "don Hernando, obispo de Avila, fino año de MCCXCII", evidentemente añadido posterior, es mencionado en un documento de 1290, deshaciéndose así el error sobre las dudas de su existencia esgrimidas por Quadrado. Este monumento así como el de Esteban Domingo afectan similitudes parciales con el monumento salmantino de D. Alfonso Vidal, deán de Ávila y arcediano de Alba ${ }^{45}$. Todos ellos se coronan con un friso de mocárabes que rematan a modo de alfiz. El uso de esta decoración se debe sin duda a la utilización de mano de obra árabe, cuya contratación pervive durante varios siglos, como lo demuestran los nombres citados en la documentación, Abdalah, Suleimán, Ibrahim. El parentesco "islámico" entre los tres monumentos podría justificarse en la relación del deán abulense, que fue enterrado en Salamanca.

El sepulcro del obispo Martín III Fernández, verdadero artífice de la catedral gótica de León, constituye una novedad en la configuración y pregona los avances artísticos del gótico radiante en el templo (fig. 5). Excavado en el muro meridional del crucero, como pilar de la Iglesia, incorpora en un enfeu un sistema de abovedamiento propio evocador de la construcción de la catedral con las tres naves de que consta rematadas en arcos apuntados como el pórtico occidental. La intencionalidad del prelado como protagonista en la construcción de la catedral está fuera de toda duda.

-

${ }^{45}$ M. Gómez Moreno, Catálogo Monumental de España. Provincia de Salamanca, Madrid, 1967, p. 118, lám. 52, 55, 55 bis; A. CASASECA CASASECA, Las catedrales de Salamanca, León, 1993, pp. 36-37. 
La imagen del prelado, con quien el rey Alfonso X el Sabio mantuvo contradictorias relaciones de amistad-odio, tiene los ojos cerrados en plácido sueño. En la iconografía sepulcral se asocian elementos adoptados de distintas procedencias, unos de sepulcros de tipo enfeu en el claustro -maestreescuela Facundo, Pedro Yáñez-, como los dos leones a la cabecera y a los pies, la escena de las exequias y el Calvario, que repite la fórmula del sepulcro de D. Rodrigo. El programa iconográfico se estructura en dos ciclos evangélicos, la Infancia y la Pasión, junto con una escena de carácter hagiográfico en relación con el santo patrón del finado, y la referencia evangélica del Sermón de la Montaña, por medio de las bienaventuranzas, como se atestigua en la inscripción muy perdida Beatus pauper ... eat flentibus hic lebat gau... (Mt. 5, 1-11; Lc. 6, 20-26). Se trata de hacer presente el valor de la redención a través de la encarnación y la pasión, que se enfatiza con las rosetas de cuadripétalas, alusión a la humanidad de Cristo. Una enseñanza fundamental del evangelio es el amor al prójimo, cuya lección más pura se manifiesta en el citado sermón. Su inclusión en el presente contexto está justificada además por su carácter escatológico. Si la iconografía de la Infancia de Cristo deriva de la portada a ella dedicada, el episodio de San Martín partiendo la capa con el pobre parece inspirada en el tímpano de la portada derecha del crucero sur de la catedral de Chartres, invirtiéndose la disposición de los personajes y trasladando su atuendo a la moda del momento. La Epifanía se inscribe en el contexto funerario ya en época paleocristiana. El interés suscitado por este tema se debió a que los antiguos festejaban el nacimiento de Cristo el día de la Epifanía, el seis de enero, o día de la Teofanía de los magos, el día cinco. Se trata de una costumbre muy arcaica, a la que se atenían los pintores del ciclo paleofunerario $^{46}$. Desconocemos las mandas del prelado a cumplir después de su muerte, pero a través del programa indicado no cabe duda que estableció misas para distintos ciclos litúrgicos.

Si el clero imprime su condición en sus monumentos funerarios, la nobleza asocia sus creencias religiosas al orgullo de estirpe y a la exaltación de su vida como miembros del estamento social al que pertenecen. Esto se evidencia incluso en miembros de la nobleza que profesaron en la vida religiosa. El sepulcro de doña Mencía, sepultada en el monasterio palentino de San Andrés del Arroyo, es ilustrativo en tal sentido. Las escenas de la Anunciación, Natividad y Epifanía, presididas por la Crucifixión, si bien ocupan un lugar de privilegio en la cabecera de la cubierta de la yacija, quedan eclipsadas por el dominio de la heráldica: las calderas de la poderosa familia Lara, a la que la religiosa pertenecía, figuran por doquier en los cuatro frentes del sepulcro y en la propia cubierta enmarcando el báculo abacial ${ }^{47}$. Esta exaltación de la estirpe se enfatiza en uno de los sepulcros del monasterio de Palazuelos, donde la decoración se reduce exclusivamente a los escudos familiares $^{48}$. En la escultura gótica castellana la heráldica es adoptada desde el siglo XIII. El grupo de los monumentos diseminados por la Tierra de Campos en las provincias de Palencia, Valladolid y extremo oeste de León, presididos por el del infante don Felipe y su esposa Inés Téllez Girón en Villalcázar de Sirga, disponen escudos repartidos por los frentes del sarcó-

${ }^{46}$ Á FRANCO MATA, Escultura gótica en León..., cit. pp. 391-394.

${ }^{47}$ E. FERNÁNDEZ GONZÁLEZ, “Los sepulcros de la sala capitular del monasterio de San Andrés del Arroyo (Palencia)", Colegio Universitario de León, Filosofía y Letras, 1 (1979), pp. 83-97. Julia,

${ }^{48}$ C. J. ARA GIL, Escultura gótica en Valladolid y su provincia, Valladolid, 1979, p. 43.
} 
fago y orlas de los vestidos de los yacentes, en un expresivo afán de exaltación familiar. Ya en el siglo XIV el taller de Ferrand González adopta la modalidad de su talla en los cojines que sustentan la cabeza del yacente, como se ostenta en el sepulcro de Pedro Suárez de Toledo.

Las provincias de Palencia, Valladolid, este de la provincia de León y Burgos comarca de Tierra de Campos-, constituyen un referente sumamente ilustrativo para el análisis de la evolución iconográfica de los siglos XIII y parte del XIV ${ }^{49}$. El grupo de los primeros talleres de Carrión así denominado al relacionado por J. Ara con Pedro Pintor y Roi Martinez de Burueva, cuya actividad se sitúa entre 1230 y 1260, es anterior al sepulcro del infante don Felipe, en Villalcázar de Sirga, datable hacia $1274^{50}$. Los primeros sepulcros esculpidos de Carrión de los Condes muestran al yacente sobre el sarcófago. La tipología presenta peculiaridades de interés. Aparece enmarcado por sendas columnillas rematadas en un arco trilobulado, enmarque que sigue siendo adoptado en sepulcros posteriores, concretamente los relacionados con el nombre de Roi Martínez de Burueva y Bame e incluso los de Villalcázar de Sirga. Esta evocación arquitectónica ha sido puesta en relación con la ciudad de Dios o Jerusalén celeste, extremo que hay que revisar. Más bien creo que debe de tratarse de una alusión al templo donde duerme su último sueño, velado por la fiel figura de su perro. Por otra parte, el énfasis conferido a la heráldica, parece que se contrapone con la idea de la felicidad

\footnotetext{
${ }^{49}$ J. L. HERNANDO GARRIDO, "Algunas notas sobre los sepulcros de Aguilar de Campoo: ...", cit. pp. 87119; C. J. ARA GIL, Un grupo de sepulcros palentinos del siglo XIII: los primeros talleres de Carrión de los Condes, Pedro Pintor y Roi Martínez de Burueva", II Curso de Cultura Medieval, Alfonso VIII y su época, Aguilar de Campoo 1-6 Octubre 1990, Aguilar de Campoo, 1992, pp. 21-52.

${ }^{50}$ C. J. ARA GIL, “Un grupo de sepulcros palentinos del siglo XIII...", cit. pp. 21-52.
}

celeste; más bien, parece que es el orgullo de estirpe lo que se pone de manifiesto. En el caso de Alvar Fernández Podestat, en Carrión de los Condes, muerto entre 1229 y 1242 , este representante de la "nobleza vieja" descansa con la cabeza apoyada sobre un cojín y los ojos abiertos, a la espera de la resurrección. Esta actitud es bastante frecuente, aunque no exclusiva, ya que eventualmente los tiene cerrados. La calidad y riqueza iconográfica del sepulcro de Cisneros y el hecho de que se repitan los temas representados en otros ejemplares demuestra que fue modelo. En varios de ellos se asocian escenas y episodios de variado carácter.

Es muy frecuente la escena del Pantocrátor con el Tetramorfos en torno y los apóstoles a uno y otro lado, eventualmente asociado a la Crucifixión. Se trata de una representación iconográfica de larga historia, presente en el mundo románico tanto en el arte mueble como en la escultura monumental, que pervive en el mundo gótico. En mi opinión, la justificación de su presencia en la escultura funeraria está vinculada a la liturgia, herencia de libros manuscritos. Tanto sacramentarios como misales disponen el en el centro del misal dicho programa iconográfico, que se impone desde mediados del siglo XI, pintándose en sendos folios completos. La Pasión de Cristo en la cruz es el signo visible de la redención, en tanto la Majestad de Cristo constituye la referencia a la Teofanía intemporal. Ilustra el canon de la misa en relación directa con la eucaristía. Frecuentemente las cubiertas eran decoradas con estos temas, bien con placas esmaltadas - placas de encuadernación de un sacramentario o un misal ${ }^{51}$, ac-

\footnotetext{
${ }^{51}$ En Sacramentarios y Misales era frecuente que en el Canon de la Misa figuraran dos páginas ilustradas, una con la Maiestas Domini y otra con la Crucifixión, cfr. V. LEROQUAIS, Les Sacramentaires et les Missels Manuscrits des Bibliothèques publiques de France, París, MDCCCXXIV, pp. XXXIII-XXXIV.
} 
tualmente se hallan repartidas entre dos instituciones, el Instituto Valencia de D. Juan de Madrid -Crucifixión cósmica- y el Musée des Thermes de Cluny -Cristo en majestad rodeado del Tetramorfos- o esculpidas en marfil.

El sarcófago de Cisneros, como otros del taller, está decorado con el citado tema y el apostolado. En el testero figura un Calvario sintético: Cristo entre la Virgen y san Juan, referencia a la redención del finado por medio de la pasión de Cristo. Estos dos temas se repiten en una caja sepulcral conservada en el Museo de Palencia, procedente tal vez de la abadía de Benevívere y en otro procedente de santa María de Vega ${ }^{52}$. Temas vinculados al ciclo de Navidad se disponen en el frente de los pies del sepulcro de Cisneros, ocupado con la Visitación, que conforma el inicio de la redención, sustituida eventualmente por la Anunciación, que contiene el mismo sentido. Es un tema frecuente en la escultura funeraria castellana ${ }^{53}$. En monumentos exentos el frente antes indicado puede formar pendant con la escena de la Epifanía, San Miguel alanceando al dragón ${ }^{54}$. Este arcángel junto a Rafael y Gabriel figuran como intercesores de los moribundos en la liturgia desde la Alta Edad Media ${ }^{55}$. Algunos de los sepulcros montan sobre varios -generalmente cinco- leones tendidos sobre sus patas.

La citada iconografía continúa vigente a la vez que se enriquece con nuevos

\footnotetext{
${ }^{52}$ C. J. ARA GIL, “Un grupo de sepulcros palentinos...", cit. pp. 33-36.

${ }^{53}$ Sepulcro 1o de Palazuelos cfr. C. J. ARA GIL, Escultura gótica en Valladolid..., cit. p. 33.

${ }^{54}$ C. J. ARA GIL, Escultura gótica en Valladolid..., cit. p. 32

55 S. Moralejo Álvarez, "The Tomb Alfonso Ansúrez (+ 1093). Its Place and the Role of Sahagún in the Beginnings of Spanish Romanesque Sculpture", Santiago, Saint Denis and Saint Peter. The Reception of the Roman Liturgy in Leon-Castille in 1080, Nueva York, 1985, pp. 63-100.
}

elementos. Se introducen personajes del Antiguo Testamento como tipos del Nuevo, en lenguaje simbólico de San Agustín. Moisés, Aarón, David, la Sinagoga y la Iglesia, acompañan a la escena de la Epifanía del sepulcro de Cisneros. Se trata de una trasposición desde la escultura monumental, que es adoptada en alguna otra ocasión, como en dos sepulcros del Museo de Palencia, procedentes de Santa María de Vega y Benevívere (¿?). A veces, pervive el carácter monumental, como en la escena del Juicio Final del sarcófago del Museo Arqueológico Nacional, sobre el que volveré por el complejo programa iconográfico plasmado en los cuatro frentes. Este tema, más sintético, se figura en el sepulcro de Cisneros y eventualmente en pintura, como en el fondo de un sepulcro en lucillo de Vileña, actualmente descontextualizado. La escena de la Huida a Egipto, derivada iconográficamente de las portadas, tal vez podría entenderse desde el marco devocional en relación con los dolores de la Virgen.

Desconocemos el origen preciso del sepulcro palentino, actualmente en el $\mathrm{Mu}-$ seo Arqueológico Nacional (n. inv. 50233) (figs. 11-12). Tan sólo sabemos que fue propiedad de D. Antonio Olañón, que lo obtuvo por compra en la ciudad de Palencia, según consta en el Archivo de la R. Academia de B. A. de San Fernando ${ }^{56}$. Su adscripción al taller en análisis es delatada por el estilo en todo semejante. Su particular programa iconográfico ha generado el interés de la crítica artística, que ha emitido juicios diferentes ${ }^{57}$. La iconografía es más compleja

\footnotetext{
${ }^{56}$ C. J. ARA GIL, “Un grupo de sepulcros palentinos...", cit. pp. 32-33, nota 58.

${ }^{57}$ Á FRANCO MATA, Museo Arqueológico Nacional..., cit. pp. 91-94; C. J. ARA GIL, Julia, “Un grupo de sepulcros palentinos...", cit. pp. 32-33; R. SÁNCHEZ AMEIJEIRAS, "Notas sobre un arca sepulcral gótica conservada en el Museo Arqueológico Nacional", Boletín del Museo Arqueológico Nacional, XII, (1994), pp. 103-112. No comparto su hipótesis sobre su posible
} 
de lo que en principio pudiera parecer. Algunas de las escenas, que parecen claras a primera vista, no lo son tanto en una apreciación más detenida, así las que en su momento se han identificado con el Bautismo de Cristo en el río Jordán, en el frente de los pies, y la Resurrección de Lázaro en la cabecera. Yo ya formulé mis dudas en mi estudio de 1980, revisándolo trece años más tarde, donde propuse la identificación de ambas escenas con la resurrección del difunto y la asunción de su alma al cielo. Dos años después, R. Sánchez Ameijeiras, vuelve a la primera identificación, opinión que no comparto, ya que los personajes representados no responden a criterios iconográficos que lo avalen.

Aunque no se han solucionado todos los problemas, entre ellos el de la identificación del personaje, sí hay extremos que pueden estimarse como válidos ${ }^{58}$. En primer lugar el personaje sepultado es masculino, y ello se evidencia por la escena de la cabecera, donde aparece barbado. En segundo lugar, está clara la existencia de un programa iconográfico unitario que aglutina los cuatro frentes del sepulcro exento, programa sujeto a unas consideraciones muy precisas por parte del encargante o ideólogo. El orden a seguir comienza en la cabecera, donde el alma del difunto sale de la tumba para ser juzgado, sigue el frente del Juicio, que entiendo no es el Juicio Final, sino el particular del difunto. A continuación, por medio del sacrificio de la misa figurado en el otro frente mayor-, son purgados los pecados del difunto, siendo su alma elevada al cielo -frente de los pies-. Los personajes de la cabecera son, además del finado que se levanta del lecho mortuo-

-

procedencia de tierras burgalesas, pues sus argumentos parecen muy endebles.

${ }^{58}$ Para el que propuse Don Diego Martínez Sarmiento, fundador de la abadía de Benevívere, y R. SÁNCHEZ AMEIJEIRAS, García Fernández de Villamayor. rio, un clérigo con libro en la mano y dos figuras femeninas con toca y saya talar, con las manos juntas en actitud de oración. El clérigo en cuestión, no lleva nimbo, por lo que es rechazable la idea de que se trate de un santo -San Norberto, propuse yo-.

Si la escena del sacrificio de la misa responde a cánones propios de la misma, y se representa el Memento pro defunctis, el juicio presenta ciertas notas peculiares que lo alejan de los Juicios Finales góticos. Faltan por ejemplo, los ángeles trompeteros que convocan a los hombres a juicio, y asimismo San Miguel pesante de almas. Preside el juicio Cristo Juez mostrando las heridas, esquema compositivo derivado directamente del Juicio de la catedral de León. A uno y otro lado se figuran la Virgen y San Juan de rodillas, como en León. Los ángeles con los instrumentos de la pasión se tornan diáconos, como se observa en las vestiduras. Tal vez la explicación de dicha asimilación haya que buscarla en antiguos rituales, como uno galo del siglo VII, en el que ya bebieron el Sacramentario Gelasiano y el Missale Francorum. El diácono, sanctis altaris minister, desempeña un servicio que lo asimila a los ángeles [angelorum ministeriis], haciendo de él el sucesor de los siete diáconos de la comunidad apostólica. Esta doble referencia lleva aparejada una indiscutible exigencia de santidad ${ }^{59}$. La boca de Leviatán se apresta a tragar las almas de los pecadores, empujadas por diablos agresivos, mientras dos avaros sujetan una bolsa de monedas. Al otro lado, y no cabe duda que por influencia de la portada de Santa María de Toro, dos damas salvadas tocadas con la corona del triunfo, como en Notre-Dame de París, se dirigen al paraíso, donde gozan varios bienaventurados, como "frutos",

\footnotetext{
59 A. G. MARTIMORT, La iglesia en Oración. Introducción a la liturgia, nueva edición actualizada y aumentada, Barcelona, 1992, pp. 733-734.
} 
entre ramas ${ }^{60}$. Es el esquema que figura también en contexto relacionado con el mundo islámico y mudéjar, como se observa en el sepulcro de la iglesia de San Andrés, de Toledo. La figura central del frente de los pies tampoco está nimbada, extremo obligado en las representaciones de Cristo, que aparece generalmente con nimbo crucífero. Los dos personajes laterales están vistiendo el alma del difunto para su asunción al cielo, uno en actitud de colocarle una camisa y el otro sosteniendo el alba de los salvados.

El sepulcro del abad Aparicio, en el Museo Arqueológico Nacional, procedente del monasterio de Aguilar de Compoo, de fines del siglo XIII y tal vez del mismo autor que el sepulcro del arcipreste Garci González, es el más teológico de la serie de monumentos palentinos ${ }^{61}$. Procedente del monasterio de Santa María la Real de Aguilar de Campoo, la yacente del abad descansa sobre el sarcófago, que en origen estaba evidentemente bajo un lucillo; no de otra forma se entiende la exclusividad decorativa en el frente anterior. En éste se figura el Credo apostólico. La Trinidad fundamenta la teología del dogma católico, y como tal se refleja en la larga serie de Credos redactados en los primeros siglos ${ }^{62}$ si bien la formulación del Credo apostólico ${ }^{63}$ y del nicenoconstantinopolitano ${ }^{64}$ han predominado sobre las demás. Los doce artículos de que se compone se han atribuido tradicionalmente a cada uno de los apóstoles. El Credo

\footnotetext{
${ }^{60}$ T. PÉREZ HigUERA “El Jardín del Paraíso: paralelismos iconológicos en el arte musulmán y cristiano medieval", Archivo Español de Arte, 241 (1988), pp. 3752.

${ }^{61}$ Á FRANCO MATA, Escultura gótica en el Museo Arqueológico Nacional, 2ª ed, Madrid, 1993, pp. 100-102.

62 J. N. D., Kelly, Primitivos Credos Cristianos, Salamanca, 1980.

${ }^{63}$ J. N. D., Kelly, Primitivos Credos Cristianos, cit. pp. 433-509.

${ }^{64}$ J. N. D., Kelly, Primitivos Credos Cristianos, cit , pp. 247-313; 353-393]
}

da comienzo con el primer artículo con Dios Padre como creador y Padre de Jesucristo. Aunque se menciona la concepción de éste en el seno de María, se enfatiza de forma especial el proceso de su pasión, sufrida para la salvación del género humano. El Espíritu Santo configura varios de los artículos siguientes, continúa la referencia de la obra salvadora por medio de la Iglesia y concluye con el Juicio Final, en el que se juzgarán las obras del hombre, en su uso de la libertad responsable. El dogma trinitario explicita que si el Hijo es la Palabra Verbum- que el Padre pronuncia y se hace carne, el Espíritu la manifiesta y la hace oír en el Evangelio, pero él mismo permanece escondido, misterioso, silencioso, "el no hablará de sí mismo" (Jn. 16, 13).

La iconografía ha interpretado de variadas formas la imagen trinitaria, como ha analizado G. de Pamplona ${ }^{65}$. El relieve del sarcófago aquilarense adopta la modalidad denominada "trono de Gracia", fórmula surgida a mediados del siglo XIII. El Padre entronizado, coronado, sostiene a Cristo crucificado. De su boca sale la Paloma del Espíritu Santo que planea en dirección a la del Hijo, frecuente en el arte hispánico de los siglos XIV y XV. Se trata de una dirección no muy acorde con el II concilio de Lyon (1274), ni con la fórmula precisa del XI Concilio de Toledo: "Nec de Patre procedit in Filium, sed simul ab utrisque procedere monstratur". La Trinidad está inscrita en un círculo alusivo al cielo. Los apóstoles, cobijados por parejas bajo arcos, son portadores de finas y largas filacterias, pero no creo que llevaran en origen el correspondiente texto. Son reconocibles los Príncipes de la Iglesia, San Pedro y San Pablo, en los lugares destacados de la jerarquía; portan el primero las llaves y el segundo su atributo

\footnotetext{
${ }^{65}$ G. de PAMPlona, Iconografía de la Santísima Trinidad en el arte medieval español, Madrid, 1970, pp. 99100.
} 
martirial, la espada en alto. Entre los arcos resaltan torrecillas, de cuyos vanos asoman cabecitas tonsuradas, evocación de la presencia de la comunidad religiosa. Los seres fantásticos que pueblan los bordes del frente aluden indudablemente al pecado, que es vencido por la fe del finado.

La nobleza en su afán de su valoración social, incluye escenas relativas a su vida de solaz. Es frecuente la referencia al deporte favorito de los caballeros en vida, la caza, cuando no se hallaba ocupado en la guerra, como se observa en la efigie del yacente del la iglesia de San Pedro de Cisneros -anteriormente en Villafilar-, el halcón, además de un puñal. El halcón parece una representación típicamente hispánica de la escultura funeraria ${ }^{66}$. A dicha iconografía responde el caballero joven, posiblemente perteneciente a la familia de Tello Pérez de Meneses [hacia 1240-1260], fundador del monasterio de Trianos (León). Aunque era una filial del monasterio de Benevívere, la proximidad al monasterio cluniacense de Sahagún tal vez justifique la inclusión de un tema de tradición leonesa, como es el Agnus Dei, adoptado en un sepulcro del monasterio de Palazuelos ${ }^{67}$.

Junto a la exaltación de la estirpe, el espectáculo de las honras fúnebres constituye una ilustración plástica de la costumbre castellana de dar el último adiós a un noble, donde a diferencia de Francia e Italia el arte sustituye, por así decirlo, a la crónica literaria. Como sucede con los programas iconográficos de carácter narrativo, sobre una base nuclear, se añaden sucesivos episodios, que la enriquecen progresivamente. La celebración de las exequias y llanto por el difunto, que tienen lugar en uno de los frentes mayores, tal vez haya que entender-

\footnotetext{
${ }^{66}$ C. J. ARA GIL, Escultura gótica en Valladolid y su provincia, cit. p. 14

${ }^{67}$ N. uno de la clasificación de C. J. ARA GIL, Escultura gótica en Valladolid y su provincia., cit. p. 33.
}

la en el sepulcro de Trianos como una de las más tempranas del taller. Se figura el momento en que el féretro ha sido depositado en el sarcófago en el interior de la iglesia y se celebra el oficio fúnebre presidido por dignidades eclesiásticas. Los dos personajes, dama y caballero, sentados, deben de ser los padres del finado, presidiendo la celebración de las exequias y los dos personajes a cada lado en pie son presumiblemente los hermanos del difunto. Su viuda sería la dama sentada con las manos cruzadas sobre el pecho en el frente de los pies. Estamos ante un acto religioso, en el que la familia ocupa un lugar destacado en la celebración de las honras fúnebres. Pero su actitud es meramente pasiva.

Todavía no ha hecho acto de presencia el ceremonial de gran aparato que constituye un espectáculo urbano en el que participa toda la población. En Castilla, la iconografía es la fuente informativa más completa y expresiva de este tipo de manifestaciones nobiliario. Ella proporciona datos plásticos a través de los cuales se puede reconstruir el desarrollo de las ceremonias de traslado del féretro desde la casa mortuoria hasta la iglesia, que coincide con el ritual litúrgico de los Ordines romani. El desarrollo de éste obedece a cuatro pasos sucesivos: A) Los ritos funerarios en casa, que incluyen la preparación del cadáver, su colocación en el féretro y las antífonas y salmos de estos ritos. B). El cortejo o procesión hasta la iglesia donde se celebrarán las exequias, con los salmos y antífonas previstos para el traslado. C) El servicio litúrgico en la iglesia, comparable al ordenamiento de un oficio de maitines. D) La colocación en la tumba ${ }^{68}$, precedida de otro cortejo de salmos y antífonas y realizado con el acompañamiento del canto pascual del salmo 117

\footnotetext{
${ }^{68}$ D. SICARD, "La muerte del cristiano", La Iglesia en oración..., cit. p. 808 .
} 
Confitemini Domini y de su antífona Aperite mihi portas.

"Suenan las campanas con su tañido característico. Los cirios iluminan una estancia acondicionada para acompañantes muy concretos; huele a cera. El color negro se impone en la vestimenta de muchos vecinos de la localidad. La casa, la calle, la iglesia; una persona, su familia, el clero, todo el vecindario participará en un acontecimiento comunitario en recuerdo de un fallecido. Se iniciaba el ritual y el aparato funerario.

Ante los allegados y toda la comunidad, también con las miras puestas en la Divinidad, se desarrollaban las exequias mortuorias. Desde la habitación como primer escenario, alrededor del lecho del moribundo, comenzaba una comitiva que transcurriría por espacios públicos habituales para el finado hasta pasar a descansar eternamente en lugar sagrado y finalizar bajo una losa" ${ }^{\prime \prime 9}$.

Este ritual documentado para las ceremonias funerarias durante el Antiguo Régimen es la continuación de las celebradas durante los siglos bajomedievales, como se colige de las representaciones escultóricas talladas en los propios monumentos funerarios. El desarrollo de la liturgia de los funerales comienza en la casa mortuoria. El sacerdote acude con una cruz, el agua bendita y la luz para ayudar al cristiano a bien morir, rezando la oración Deus apud quem monia morientia. Ya fallecido, da comienzo el ceremonial con una serie de actos practicados en la misma casa y finaliza en la iglesia donde se celebraba el funeral y se enteraba el cadáver. En primer lugar el difunto recibe la absolución y posteriormente se procede a preparar el cuerpo para el eterno reposo: era lavado, ungido y perfumado, trasunto de la operación efectuada en el

\footnotetext{
${ }^{69}$ M. GARCÍA FERNÁNDEZ, Los castellanos y la muerte. Religiosidad y comportamiento colectivos en el Antiguo Régimen, Valladolid, 1996, p. 303.
}

cuerpo de Cristo. Era vestido bien con sus ropas más nobles o con un hábito religioso, extremo ordenado en vida por el finado en el testamento. A continuación los familiares y deudos se reúnen en torno al cuerpo expuesto en el lit de parade, mientras el clero eleva sus plegarias rituales por el eterno descanso de su alma. La exposición del cuerpo, que al principio se hacía en la iglesia, pasó a realizarse en la casa señorial o palacio cuando se trataba de un personaje relevante. Eventualmente el cuerpo era embalsamado o sustituido por la efigie, pues sabemos a través de los testamentos que a veces se ordenaba la prohibición de ser visto el rostro después de muerto. Las ceremonias en la casa finalizaban con la incensación y el asperges con agua bendita sobre el cadáver.

Continúa el ceremonial en la calle, con el cortejo fúnebre, muchas veces de gran ostentación. Según Vovelle es la prolongación natural de la exposición de aquél en su casa. Eran frecuentes los legados generosos por parte de los testadores para conseguir una importante afluencia de público, lo cual no era extraño teniendo en cuenta la mentalidad de la Baja Edad Media, tan dada a manifestaciones exageradas en todo tipo de situaciones, tanto para el dolor como para la alegría, como ha dejado patente J. Huizinga El otoño de la Edad Me$\mathrm{dia}^{70}$.

Abre el cortejo religioso la cruz, como procede en las ceremonias dedicadas a un cristiano. Detrás desfilan los plañideros y gritadores, los pobres oficiales, vestidos, alimentados y pagados en número variable en proporción al rango y generosidad del difunto, los clérigos parroquiales, canónigos y prelados, representaciones de las distintas órdenes religiosas, y de forma

\footnotetext{
${ }^{70}$ J. HuIZINGA, El otoño de la Edad Media, $8^{\underline{a}}$ ed. versión castellana del original alemán, Madrid, 1971.
} 
especial los mendicantes que prácticamente sustituyeron a las monacales, y representantes de las cofradías. Los parientes más cercanos se distinguían por el atuendo, cuyo excesivo lujo motivó sucesivas prohibiciones en el marco legal de las leyes suntuarias. El cortejo civil es encabezado por los servidores con las armas del finado, con el pendón posadero con las armas familiares, reversado, en señal de duelo. Siguen los sonadores de los instrumentos de viento, de los que las crónicas se hacen eco para diferentes manifestaciones lúdicas; el episodio de varios sepulcros vallisoletanos, evidencia la costumbre en sepelios de gran boato. Su ubicación no es constante; por el contrario, en otros monumentos castellanos del siglo XIV son desplazados a los pies de la cubierta, eventualmente acompañados de lebreles. Es el caso de los sepulcros vallisoletanos de Santa María de Palazuelos -tres-, actualmente en el Museo Diocesano y Catedralicio de Valladolid ${ }^{71}$ y de Santa María de Matallana, en el Museo Nacional de Arte de Cataluña, en Barcelona. Oficiales, servidores y escuderos exhibían las piezas de honor del difunto y los escudos a la funerala, montados sobre corceles ricamente enjaezados de luto. El caballo con la cola cortada porta el escudo del caballero reversado, que a veces, por deseo explícito de aquél, debía de acompañarlo desde la casa; un dolor ritualizado en el animal, que sería adoptado los lebreles, a los que golpeaban para que aullasen $^{72}$.

La iglesia era el punto final de reunión para despedir al difunto. Allí tenía lugar el funeral y sepelio. Se procedía a organizar una decoración adecuada, que

\footnotetext{
-

${ }^{71}$ C. J. ARA GIL, Escultura gótica en Valladolid y su provincia, cit. p. 39, n. 5.

${ }^{72}$ R. SÁNCHEZ AMEIJEIRAS, "Un espectáculo urbano em la Castilla medieval: las honras fúnebres del caballero", El Rostro y el Discurso de la Fiesta, ed. M. Núñez Rodríguez, Santiago de Compostela, 1994, pp. 141-157, sobre todo.
}

podía limitarse al coro, donde se instalaba la capilla ardiente, o a todo el edificio. Allí el clero entonaba una serie de oraciones y antífonas del oficio de difuntos, como el ya indicado del Subvenite sancti Dei ocurrite angeli Domini suscipientes animam eius.... También se celebraba la misa, cuya importancia en el contexto de la muerte y liturgia de funerales es muy importante. Finalizada la misa, se procedía a la absolución del difunto, pidiendo la misericordia de Dios: Absolve quaes Domine, animam famuli tui.., se rezaba en los libros litúrgicos. Luego se bendecía el cadáver, al que se inciensaba y asperjía con agua bendita. Antes del sepelio, se procedía al rezo de las últimas oraciones y responsorios -Non intres in judicio cum servo tuo Domine...; Liberame Domine de morte eterna..., In paradisum deducant te angeli in tuo adventu...-. La antífona de esperanza Ego sum resurectio et vita pone de relieve el carácter pascual y de fe en la resurrección, que preside las exequias del cristiano.

La última parte del ceremonial correspondía al enterramiento, para el que la iglesia fue elegida frecuentemente por parte de reyes, nobles y ya a fines del gótico, ricos burgueses y mercaderes, pues se trataba de una operación económica la adquisición de un espacio para el sepulcro o una capilla funeraria personal o familiar ${ }^{73}$. Esta parte tiene bastante incidencia en la escultura, tanto del clero, que solía elegir el claustro en catedrales y monasterios, como de los miembros de la nobleza, que rivalizaban en boato.

Mientras se celebraba la ceremonia del sepelio de caballeros, los servidores procedían a batir los escudos produciendo un ruido estrepitoso, hasta conseguir romperlos. La documentación alude al quebrar los paveses y escudos de la casa y la icono-

\footnotetext{
73 J. ORLANDIS, "Sobre la elección de sepultura en la España medieval", Anuario de Historia del Derecho Español, XX, (1950), pp. 5-49.
} 
grafía lo refleja en el arte, así el sepulcro del Museo Provincial de León, episodio descubierto por R. Sánchez Ameijeiras. Los paveses del caballero, por el contrario, eran colgados en las iglesias donde eran sepultados y eventualmente en su capilla funeraria. El relieve de Esteban Domingo, caballero abulense que luchó en la conquista de Jaén en las tropas de Fernando III el Santo, ha de entenderse, según la citada investigadora, como la representación de la entrega del caballo y las armas del finado, con varios caballeros lamentándose sobre el escudo y otro llevando las riendas la montura con la gualdrapa retirada hacia atrás ${ }^{74}$. Los ruidosos llantos, la estruendosa música, el fragor de los golpes de los escudos, eran un componente que la plástica solo puede reflejar por medio de los relieves. A ello debían de sumarse las mascaradas, evocadas por medio de máscaras, como en un sepulcro de Matallana. Aunque no se documenta en nuestro país dicha costumbre, no cabe duda que existía, tal vez por influencia llegada de Francia, donde se remonta al menos al siglo $\mathrm{IX}^{75}$.

El aparato del ceremonial no quedaría completo sin las bulliciosas y ruidosas manifestaciones de dolor. Siguiendo costumbres antiguas, recogidas en los Evangelios (Mt. 9, 23), eran contratadas plañideras a tal efecto. La exageración de las manifestaciones de duelo generó prohibiciones, como mesarse los cabellos, lacerarse las mejillas, desnudarse y arañarse los brazos. Esto se contradice con las mismas actitudes, como el espectacular sepelio de Fernando III, recogido por su hijo Alfonso $X$ en la Primera Crónica General de España, donde se dice. "Et quien vio tanta duenna de alta guisa et tanta donzella andar descabennadas et

\footnotetext{
${ }^{74}$ R. SÁNCHEZ AMEIJEIRAS, “Un espectáculo urbano...", cit. pp. 149-155.

${ }^{75}$ Cfr. R. SÁnCHEZ AMEIJEIRAS, “Un espectáculo urbano...", cit. pp. 156-157. Descrito en Ara, Escultura gótica en Valladolid y su provincia, cit. p. 51.
}

rascadas, rompiendo las fazes et tornandolas en sangre et en la carne viva?. Quien vio tanto infante, tanto rico ome, tanto infançon, tanto cavallero, tanto ome dando bozes mesando sus cabellos et ronpiendo las fuentes et faziendo en sy fuertes cruezas?". Aquí se pone de manifiesto el dolor del hijo ante la muerte del padre. Manifestaciones de dolor exageradas son prohibidas por el Cabildo de Burgos en 1334: "Que los parientes ni los criados ni otros ningunos omes non vayan a las siellas del choro nin fagan llanto en el coro demientre que dixeren la misa o el cuerpo estidiere en el choro...".

El taller palentino se hace eco de la escenografía desarrollada en las exequias de nobles y caballeros, así en uno de los sepulcros conservados en el Museo de Palencia, procedente de Santa María de Vega, del que se ha propuesto su pertenencia a Gómez Ruiz Manzanedo (+ 1275) ${ }^{76}$. También se representó en el desaparecido de Don Rodrigo González Girón, que murió en un torneo, según informa el relieve de los pies, y recibió sepultura en el monasterio cisterciense de Benavides. Se ha enfatizado el tipo de muerte en el uso de las armas, es decir, la profesión del caballero. El sepulcro del monasterio de Benavides estaba firmado por Roi Martinez de Burueva y de Bame. El hecho de coincidir la descripción con la representación del sepulcro de Vega, sugiere que perteneciera al mismo taller, según observa J. Ara, lo cual constituye un dato de extraordinario interés. No cabe duda de que el autor se sentía orgulloso de su obra.

La literatura artística se ha hecho eco con justicia de los sepulcros reales de la abadía de Fontevraud $^{77}$. Jean-Pierre Gaborit

\footnotetext{
${ }^{76}$ R. SÁNCHEZ AMEIJEIRAS, “Un espectáculo urbano...", cit. pp. 141-157.

${ }^{77}$ L. COURAJOD, “Les sculptures des Plantagenêts à Fontevraud (1183-1867)", Gazette des Beaux-Arts, XIII (1857), pp. 537-558; R. CROZET, “Note sur les monuments funéraires de l'abbaye de Fontevraud", Bulletin de la Société des Antiquaires de l'Ouest, 1966, 7 págs.; E. PANOFSKY, Tomb Sculpture...., cit. p. 57; A.
} 
ha incidido sobre el lit de parade -"'Sur un lit de parade" essai d'interpretation d'un motif funéraire'- sobre el que yacen las imágenes funerarias de los reyes allí sepultados ${ }^{78}$, expuestos en la capilla ardiente, ritual introducido en Inglaterra en la segunda mitad del siglo XII ${ }^{79}$. El lecho aparece invisible, pero se adivina bajo la tela que lo recubre completamente, incluso los extremos de los cuatro montantes de similar altura, probablemente torneados, dice el citado autor. Se nota asimismo la presencia de un travesaño debajo, en tanto un cojín sirve de apoyo para la cabeza de los yacentes, colocado directamente sobre la tela, que cae lateralmente formando regulares y estilizados pliegues. Evidentemente los regios personajes desearon perennizar un momento preciso del ceremonial de los funerales reales, es decir, la exposición solemne del cuerpo revestido de sus insignias, de donde el término "lit de parade". Este autor se hace eco de la escasa incidencia del tipo en Francia, además de indicar su carácter de "anachronisme par lequel nous transposons 'l'appareil des grandes funérailles' à une époque où l'idée même d'une telle exaltation de la personalité d'un défunt, fut-il royal, est encore absente". Se han propuesto como las primeras efigies las de Enrique II (+ 1189) y Ricardo Corazón de León (+ 1199), encargadas tal vez por la viuda del primero, Leonor de Aquitania, antes de su muerte en 1204. Mientras ella sostiene un libro en actitud de leer, su esposo sostiene el cetro entre las manos y a su izquierda reposa la espada envainada. En

ERLANDE-BRANDENBURG, “Les gisants de Fontevraud", La figuration des morts dans la chretienté médiévale jusqu'à la fin du premier quart du XIVe siècle, Fontevraud, 1988, pp. 3-12.

78 J.-P. GABORIT, "'Sur un lit de parade' essai d'interpretation d'un motif funéraire", La figuration des morts dans la chretienté médiévale jusqu'à la fin du premier quart du XIVe siècle, Fontevraud, 1988, pp 117-123.

${ }^{79}$ P. WiLliamson, Escultura gótica 1140-1300, version castellana del original inglés, Madrid, 1997, pp. 92-93. cuanto a la cuarta yacente, realizada en madera, se ha propuesto identificarla con Isabel de Angulema, propuesta no definiti$v a^{80}$ En Italia, a diferencia de Francia, gozó de bastante fortuna, penetrando posiblemente desde la zona norte $\mathrm{u}$ oeste de los Alpes, y en orden del tiempo se prolongó hasta el barroco.

El lit de parade es el lecho mortuorio con un paño encima sobre el que se dispone al difunto una vez limpio y aseado. Desde el punto de vista iconográfico constituye una modalidad figurativa que se corresponde con las ceremonias litúrgicas celebradas durante las exequias. La figuración plástica del paño sobre el que se colocaba al finado se registra en distintas regiones del país. Sin embargo, su existencia se rastrea ya en el arte románico. Es espacialmente significativo el monumento sepulcral, ya indicado, de la iglesia de la Magdalena de Zamora $^{81}$. Obra novedosa, que se ha puesto en relación con el arte compostelano contemporáneo, recuerda esquemas compositivos que tendrán larga vida en la escultura gótica italiana. La disposición y dimensiones de los dos ángeles turiferarios parecen precedentes de los ángeles reggicortina de los grandes sepulcros góticos de Toscana, Roma y Campania. En España, sin embargo, no dejó secuelas para dicha iconografía y muy escasamente para el yacente sobre el lit de parade. Del siglo XIII es el sepulcro del arzobispo D. Rodrigo Jiménez de Rada (+ 1247)-siglo XIII-, en el monasterio de Santa María de Huerta (Soria), compuesto de

80 A. ERLANDE-BRANDENBURG, "Le gisant d'Isabelle d'Angoulême", Isabelle d'Angoulême, comtesse-reine et son temps (1186-1246), Actas del Coloquio celebrado en Lusignan 8-10 nov. 1996, Centre d'Études Súperieures de Civilisation Médiévale, 1999, pp. 129-133.

${ }^{81}$ M. RuIz MALDONADO, "Dos obras maestras del románico de transición: "La portada del Obispo y el sepulcro de la Magdalena", Stvdia Zamorensia (Anejos). Arte medieval en Zamora, Zamora/Salamanca, 1988, pp. 33-59, sobre todo pp. 39-47, figs. 12-30. 
sencilla lauda con la figura de medio yacente -a caballo entre la lauda y la escultura yacente-, bajo el que asoma una cubierta de tela rematada en flecos. Se registra sobre todo a partir del siglo XIV, siendo Galicia la región de mayor dispersión.

El lit de parade está enmarcado en varios sepulcros castellanos en del programa iconográfico de las exequias. De entre todos destaca el monumento del infante don Felipe $(+1274)$, sepultado en el monasterio templario de Villalcázar de Sirga. El sepulcro exento recoge con todo lujo de detalles el desarrollo del citado acontecimiento luctuoso, donde se figura el lit de parade, así como en el de su esposa dña. Inés Téllez Girón. La escena tiene lugar en uno de los frentes mayores, aunque en otros casos es trasladada al frente de la cabecera, modalidad presente en sepulcros tanto palentinos -Inés Rodríguez de Villalobos ${ }^{82}$ (fig. 13)como vallisoletanos -Palazuelos y Matallana ${ }^{83}$-. La peculiaridad de los monumentos castellanos es que el difunto expuesto sobre el lit de parade está rodeado de familiares y allegados en conmovedor llanto, con las manos sobre el rostro. A diferencia de algunos sepulcros de clérigos, como el deán Fernando Alonso en la catedral vieja de Salamanca, en Burgos generalmente se elimina dicha escena, como en los sepulcros de los obispos D. Pedro Rodríguez de Quijano y D. Gonzalo de Hinojosa, quedando tan sólo la del yacente cubierto en el lecho y la introducción del cadáver en el sarcófago.

Desconozco la existencia del lit de parade en León, pero se rastrea algún ejemplar en la provincia de Burgos, como una yacente de madera de un caballero sepultado en Vileña y trasladado hace años a Villarca-

\footnotetext{
82 Á Franco Mata, Museo Arqueológico Nacional. Catálogo de la escultura gótica, cit. pp. 102-103, n. 77.

${ }^{83}$ N. 1-4, 8 del catálogo de C. J. ARA GIL, Escultura gótica en Valladolid y su provincia, cit. pp. 32-53.
}

yo $^{84}$. Tal vez de Burgos se difunda a otras regiones del norte de España, como Asturias y Álava. En Galicia, creo que penetra desde Inglaterra en fecha relativamente temprana. El sepulcro del almirante y poeta Payo Gómez Chariño, enterrado en San Francisco de Pontevedra es obra tal vez de comienzos del siglo XIV, que a más de su disposición sobre el lit de parade, cruza las piernas, al modo inglés, convención adoptada del foco castellano, que analizaré más adelante ${ }^{85}$. Otros ejemplares de caballeros gallegos se conservan en los conventos de Santo Domingo y San Francisco de Pontevedra. D. Diego Álvarez de Sotomayor el Mozo (ca. 1400-1405) y su hijo D. Payo Gómez de Sotomayor fueron inhumados en la capilla de Santo Tomás del convento dominico $^{86}$. Se trata de una fecha ya tardía y aún más lo son los monumentos castellanos de San Esteban de Cuéllar (Segovia) ${ }^{87}$, con los yacentes Juan Velázquez de Cuéllar e hijo Juan Velázquez, donde se desarrolla la ceremonia de la liturgia de los funerales, o el hermoso sepulcro de doña Constanza de Castilla, realizado en fino alabastro, actualmente en el Museo Arqueológico Nacional, procedente de Santo Domingo el Real de Madrid ${ }^{88}$. Particularmente expresivo es el del caballero D. Diego de Anaya.

\footnotetext{
${ }^{84}$ Los sepulcros de Vileña fueron dados a conocer por M. MARTínez BuRgos y J. L. de MONTEVERDE, "Los sepulcros de madera policromada del Monasterio de Vileña", Homenaje a Mélida. Anuario del Cuerpo Facultativo de Archiveros, Bibliotecarios y Arqueólogos, Madrid, 1935, p. 183; Museo de Vileña (Burgos), Memorias de los Museos Arqueológicos Provinciales 1943, Extractos, IV (1944), pp. 202-203.

${ }^{85}$ S. MORAlEjo ÁlvareZ, Escultura gótica en Galicia (1200-1350), Santiago de Compostela, 1975, p. 28.

${ }^{86}$ C. MANSO PORTO, Arte gótico en Galicia: los dominicos, cit. II, pp. 511-512, láms. 73-74.

${ }^{87}$ Á FRANCO MATA, “Arte y Liturgia: un fondo de lucillo gótico en el Museo Arqueológico Nacional", en Homenaje a la profesora CARMEN ORCÁSTEGUI GROS, Zaragoza, 1999, I, pp. 563-571.

${ }^{88}$ Á Franco Mata, Museo Arqueológico Nacional. Catálogo de la escultura gótica, cit., pp. 109-112, n. 91.
} 
Descrito con su proverbial maestría por M. Gómez Moreno ${ }^{89}$, ha reparado en él Bialostoki, quien escribe lo siguiente: “... tumbado sobre un colchón y unas almohadas, muy minuciosamente representadas, pero está vestido con su armadura; se podría pensar que la escena representada es la de un caballero yaciendo en su capilla ardiente" ${ }^{\prime \prime 90}$, es decir, sobre su lit de parade.

El siglo XIV aporta algunas novedades iconográficas, vinculadas sin duda con la transformación experimentada por la nobleza ${ }^{91}$ en aras a subrayar su identidad en el marco social. El sepulcro del caballero Fernán Pérez de Andrade enfatiza la ocupación cinegética del posesor, como se pone de manifiesto no sólo en el propio sepulcro, sino en los relieves de los muros de la igle$s i a^{92}$. Dos miembros de la conocida familia de los Rojas, D. Día Sánchez de Rojas (+ 1349) y Sancho Sánchez de Rojas (Nájera, + 3 de abril de 1367) (fig. 15), hacen resaltar sobre sus sepulcros importantes hechos de armas protagonizados por ellos, recogidos en las Crónicas. Son testimonios fehacientes de su afirmación nobiliaria, narrados como una "crónica iconográfica". El primero es mencionado en las Crónicas de los Reyes castellanos. Es probable que muriera a consecuencia de la peste en el sitio de Gibraltar, lo que justificaría la inclusión de la lucha naval. Esta hazaña, plasmada en el

${ }^{89}$ M. Gómez Moreno Catálogo Monumental de España. Provincia de Salamanca, , pp. 123-124, fig. 65.

${ }^{90} \mathrm{~J}$. BIAlOSTOCKI, El arte del siglo XV. De Parler a Durero, versión española del original italiano, Madrid, 1998, p. 412.

${ }^{91}$ S. de MoxÓ, “De la Nobleza Vieja a la Nobleza Nueva. La transformación nobiliaria castellana en la Baja Edad Media", Cuadernos de Historia, 3 (1969), p. 170.

92 M. NúÑEZ RODRÍGUEZ, “El sepulcro de Fernán Pérez de Andrade...", cit. pp. 1-19; C. MANSO PORTO, Arte gótico en Galicia: los dominicos, cit. I, cap. IV-VI, C. MANSO PORTO, "El mundo profano en la imaginería gótica de los conventos mendicantes gallegos: la caza", cit. pp. 231-253. costado mayor del sarcófago, se completaría con otro hecho de armas, una batalla campal, en la cabecera. Los relieves perdidos seguramente aludían a las exequias, como en el sepulcro de Don Sancho. En este último se enfatizan acontecimientos fundamentales de su biografía caballeresca, detallando dos episodios especialmente importantes, con la presencia del rey, seguramente Alfonso XI. Tal es el caso de la escena en que es investido caballero por el monarca ${ }^{93}$, pues creo que a este acontecimiento se refiere uno de los relieves ${ }^{94}$, en su sepulcro de madera del monasterio de Vileña (Burgos) -actualmente en Villarcayo ${ }^{95}$. Como en la escena del rey Mentón ordenando caballeros a sus hijos, en el Libro del Caballero Cifar, el rey aparece de pie y ellos de rodillas ${ }^{96}$. Quizá se deba de entender como el origen del interés por la narración de acontecimientos destacados de la vida de diversos caballeros, que se justifican en el presente contexto por referirse a la denominada muerte heroica. No cabe duda de que se ha puesto en evidencia el subrayar la categoría social del caballero, gran soldado en la crucial batalla del Salado (1340). Gran sentimiento debió de aquejar al monarca Enrique II?-, que acude a dar el último adiós sobre el lecho mortuorio. Varios episodios de su vida se integran en los frentes de la caja mortuoria, a través de los cuales

${ }^{93}$ N. R. PORRO GIRARDI, La investidura de armas en Castilla del Rey Sabio a los Católicos, Valladolid, 1998.

${ }^{94}$ N. R. PORRO GIRARDI, (La investidura de armas en Castilla del rey Sabio a los Católicos, cit. pp. 149-168), es interesante desde el punto de vista histórico, pero no iconográfico. J. M. NIETO SORIA, Ceremonias de la realeza. Propaganda y legitimación en la Castilla Trastámara, Madrid, 1993, pp. 73-76.

${ }^{95}$ M. NúÑEZ RODRÍGUEZ, Manuel, "El discurso de la muerte: muerte épica, muerte caballeresca", Archivo Español de Arte, 269 (1995), pp. 17-30; M. RUIZ MALDONADO, "Escultura funeraria en Burgos: los sepulcros de los Rojas, Celada y su círculo", Boletín del Museo e Instituto “Camón Aznar", 56 (1994), pp. 45-126.

96 J. M. NiETO SORIA, Ceremonias de la realeza..., cit. lám. 4. 
conocemos la trayectoria militar. A diferencia de este gusto por la narración, caballeros toledanos se muestran remisos a la hora de invocar sus hechos de armas. Sirva de ejemplo el caballero toledano Pedro Suárez muerto en la batalla de Troncoso. En su sepulcro solamente se expresa su prosapia familiar por medio del escudo y su franciscanismo: sobre el atuendo militar va ataviado con el hábito de san Francisco que se suma a otras evocaciones a esta orden, como el cordón que rodea sus escudos.

La Caballería gozó de numerosos privilegios y prebendas en Castilla, sobre todo por su entronque con la nobleza. La investidura de armas de los caballeros era privativa de monarcas o personas muy allegadas a ellos. Dejando aparte la intrusión de villanos por motivos relacionados con la siempre menguada economía regia, los caballeros vestían sus más nobles galas en las citadas ceremonias, como sabemos sobre todo a través de las Partidas. Después de la vela de las armas la noche anterior y el aseo personal, vestían la camisa, el brial y el manto, calzaban las espuelas, y ceñían la "espada en cinta" y el escudo ${ }^{97}$. Menciono estos extremos, pues será dicho atuendo el que luzca el caballero en su lecho mortuorio. Los caballeros van vestidos con traje de milicia y sostienen la espada con ambas manos o una de ellas cruzada sobre el pecho. Dicho instrumento bélico está sujeto a un simbolismo relacionado con las virtudes que deben de acompañar al caballero, prudencia [cordura], fortaleza, templanza [mesura] y justicia: la prudencia está simbolizada en el mango; la fortaleza en la manzana, en el arriaz la templanza y la justicia en el hierro ${ }^{98}$. Estas virtudes se incardinan a devociones, entre las que ocupa un lugar de

\footnotetext{
${ }^{97}$ N. R. PORRO GIRARDI, La investidura de armas en Castilla del Rey Sabio a los Católicos, cit. pp. 143-179.

${ }^{98}$ N. R. PORRO GIRARDI, La investidura de armas en Castilla del Rey Sabio a los Católicos, cit. pp. 85-91.
}

preferencia la Virgen; no en vano se conservan ejemplares de espadas con la invocación Ave Maria -Museo Arqueológico Nacional ${ }^{99}$-, que figura en la yacente del osario del caballero Pere Sitjar en Rocafort del Bages (Barcelona), fuera de nuestro territorio, por tanto ${ }^{100}$. A las virtudes reseñadas se añaden a veces conceptos de carácter taumatúrgico. Tal es el caso de la yacente del caballero Fernán Pérez de Andrade, cuya espada ostenta el nudo de Salomón [contra los temblores de la tierra] y la estrella de David [contra la muerte accidental], signos protectores aceptados por la Iglesia $^{101}$.

La incidencia de modas foráneas se evidencia sobre todo en personajes, gran parte de cuya vida ha transcurrido en el extranjero. Tal es el caso del cardenal D. Gil Álvarez de Albornoz, que vivió muchos años en Bolonia, de cuyo colegio de San Clemente fue fundador. Participó de la moda extendida por Europa de doble sepulcro, uno para las vísceras, ya desaparecido, en Asís, y el de su cuerpo en la catedral de Toledo, para cuya capilla sacrificó

\footnotetext{
${ }^{99}$ N. Inv. 52353. Á FRANCO MATA, “Antigüedades medievales del siglo VIII al XV", en Guía General del Museo Arqueológico Nacional, 2a ed., Madrid, 1996, p. 234.

${ }^{100}$ F. ESPAÑOL BERTRÁN, “El escultor trecentista Berenguer Ferrer: un eslabón más en la penetración del arte francés en Cataluña", Anuario del Departamento de Historia y Teoría del Arte, II, Madrid, 1990, pp. 75-96, sobre todo p. 80. Este escultor identificado por Francisco de Caso y Pedro Paniagua Félix (El arte gótico en Asturias, Gijón, 1999, pp. 243-244) como el autor de una estatua de San Miguel, en el Museo de la Iglesia de Oviedo, procedente de Bárcena del Monasterio (Tineo), que yo publiqué erradamente como obra inglesa (Á FRANCO MATA, El retablo gótico de Cartagena y los alabastros ingleses. en España, Murcia, 1999, p. 124, fig. 121, corregido en A. FRANCO MATA, "Apostillas a la publicación El retablo gótico de Cartagena y los alabastros ingleses en España", El Punto de las Artes, 563,2000, p. 33.

101 D. AleXANDre-BIDON, La mort au Moyen Age XIIIe-XVIe siècle, cit. p. 41.
} 
tres en torno a la girola ${ }^{102}$. Gonzalo Gudiel se hizo enterrar el cuerpo en Roma y las vísceras en Viterbo. Dicha costumbre de partir el cuerpo,-Alfonso X el Sabio ordenó que su cuerpo reposara dividido en tres sepulturas- llegó a alcanzar tal grado de exageración, que el papa Bonifacio VIII la prohibió con extremo rigor, como un, detesdandae feritatis abusus quem ex quodam more horribili nonnulli fideles improvide prosequun$t_{u r}{ }^{103}$. Pero la inquietud hacia dicha costumbre venía de atrás. El liturgista Guillermo Durand recuerda que sólo puede inhumarse en tierra consagrada "el cuerpo entero del hombre, y también la cabeza solamente...", extremo éste último relacionado con los enterramientos de mártires degollados ${ }^{104}$. También los soberanos europeos participaron de dicha moda, así los reyes alemanes y los franceses. Los reyes alemanes se hacían enterrar aparte las entrañas ${ }^{105}$. La nobleza tampoco es ajena a dicha moda ${ }^{106}$. El monumento funerario del cardenal, exento, se ubica en el centro de la capilla, que hará fortuna en el ocaso de la

-

102 Á FRANCO MATA, Ángela, “Relaciones hispanoitalianas de la escultura funeraria del siglo XIV", en M. NúÑEZ RODRíGUEZ, y E. PORTELA SILVA, (eds.) La Idea y el Sentimiento de la Muerte en la Historia y en el Arte de la Edad Media, Santiago de Compostela, 1988, pp. 99-125.

${ }^{103}$ J. Huizinga, El Otoño de la Edad Media, cit. p. 221; E. A. R BROWN, "Death and the human body in the later middle ages: the legislation of Boniface VIII on the division of the corpse", Viator, 12 (1981), pp. 221-270. Agradezco la publicación a Felipe Pereda.

${ }^{104}$ D. AlEXANDRE-BidON, La mort au Moyen Age XIIIe-XVIe siècle, cit. pp. 203-204.

105 J. EHLERS, "Pratiques funeraires et sepultures des rois allemands de Henri 1er à Henri V", La figuration des morts dans la chretienté médiévale jusqu'à la fin du premier quart du XIVe siècle, Abbaye Royale de Fontevraud. Centre culturel de l'Ouest, 1er Cahier de Fontevraud, 1988, pp. 209-222, sobre todo p. 213.

${ }^{106}$ Foulque Nera y Ricardo Corazón de León son dos ejemplos significativos. Incluso hay abadías especializadas en enterramientos de vísceras, como es el caso de Fontevraud, que acogió el corazón de Robert d'Arbrissel, Juan sin Tierra, Henri III Plantagenêt y su hija, cfr. D. Alexandre-Bidon, La mort au Moyen Age XIIIe-XVIe siècle, cit. p. 204.
Edad Media. El yacente, ataviado de pontifical, sobre un sarcófago exornado con extraordinario derroche decorativo, viste de pontifical con gran cuidado en la ejecución, motivado por el material, alabastro. Estimo de interés llamar la atención en cuanto al espacio en torno al sepulcro, marcado para las procesiones.

Si el monumento de Albornoz se inscribe parcialmente en corrientes foráneas, otro tanto hay que decir del sepulcro del arzobispo Pedro Tenorio, o en su capilla funeraria de San Blas, y junto a él el de don Vicente Arias de Balboa. La influencia italiana se refleja en el estilo, tanto en la escultura como en el programa pictórico en relación con la fe, manifestada a través del Credo. De hecho con el símbolo de la fe comenzaban generalmente los testamentos. Las estatuas yacentes vestidas con atuendo litúrgico, muestran rostros beatíficos como corresponde a los que ya han entrado en el cielo por la misericordia de Dios, la intercesión de los santos y oraciones de los fieles.

El yacente aparece a veces acompañado por ángeles, sobre cuya presencia se han vertido diversas explicaciones, no siempre convincentes. Se hallan situados a la cabecera del yacente, y eventualmente a los pies y hacia el medio. Ya he indicado la existencia de ángeles en el sepulcro de la Magdalena, cuyo tamaño es excepcional en la plástica hispana. Lo más frecuente son ángeles de pequeño tamaño, importación de Francia ${ }^{107}$, como los yacentes en actitud de oración. Aparte de los ejemplos de los sepulcros de San Pedro de Osma, en abigarrada mezcla con una serie de personajes, y el de Santo Domingo de la Calzada, conviene señalar los ejemplares que corresponden al tipo en análisis. Uno de los primeros ejemplos serían los acompañantes de

107 Á FRANCO MATA, Escultura gótica en León y provincia, cit. p. 405. 
la yacente de la abadesa Beata (+ 1262), en el monasterio de Cañas (La Rioja), del último cuarto del siglo XIII, en torno a $1275^{108} \mathrm{y}$ unos años más tarde el sepulcro de doña Urraca López de Haro (fig. 14), sepultada en el monasterio de Vileña y trasladado el sepulcro de Villarcayo ${ }^{109}$. Resulta sorprendente la ausencia de ángeles acompañando al yacente en ámbito leonés en el siglo XIII, tan vinculado con el vecino país, y donde se prodiga a lo largo del siglo XIII en sepulcros de diversos estamentos sociales. Es adoptado por personajes del clero, nobles y caballeros ${ }^{110}$, tanto en laudas como en sepulcros monumentales, uno de los cuales corresponde al obispo de Evrard de Fouilly en la catedral de Amiens. Las tumbas reales, como en el sepulcro ya perdido de Felipe de Francia, lo adoptan tempranamente y dejan de usarlo en el siglo XIII.

Dicho elemento es asimismo adoptado en multitud de sepulcros gallegos de los siglos XIV y XV, prologados por el ya citado del poeta P. Gómez Chariño. En el primero de los siglos citados constituye una convención típica del taller toledano de Ferrand González. En los sepulcros de la capilla de Reyes Nuevos de la catedral aparecen a la cabecera de los reyes cuyas yacentes se conservan, Enrique II (+ 1379), su esposa Juana Manuel (+ 1381), Enrique III (+ 1406) y su esposa Catalina de Lancaster (+ $1418)^{111}$. Tanto este elemento iconográfico, como la adopción del cojín en los yacentes

\footnotetext{
108 M. Ruiz MaldONADO, Margarita “Escultura funeraria del siglo XIII: los sepulcros de los López de Haro", Boletín del Museo e Instituto "Camón Aznar", LXVI (1996), pp. 91-169, sobre todo pp. 120-124.

${ }^{109}$ M. RUIZ MALDONADO, "Escultura funeraria del siglo XIII...", cit. pp. 127-133.

${ }^{110}$ Para su representación en sepulcros de caballeros, vid. A. MUSSAT, "Le chevalier et son double: Naissance d'une image funéraire (XIIIe siècle)", La figuration des morts, pp. 138-154.

111 T. PÉrez Higuera, “Los sepulcros de Reyes Nuevos (Catedral de Toledo)" Tekné, 1 (1985), pp. 131139.
}

de caballeros, proviene del estamento eclesiástico $^{112}$, siendo adoptado por los demás estamentos sociales. Eventualmente reyes y pontífices utilizan hasta tres. El Maestro del Juicio Final de la catedral de León, autor del sepulcro del deán Martín Fernández (fig. 6), en el claustro, para el que se inspira en sepulcros franceses con dicho tema, no lo incluye. Sirva de referencia para su composición arquitectónica el sepulcro de Felipe Dagoberto y de Luis de Francia, conservado actualmente muy fragmentado, pero interesante por varios conceptos. También tenemos referencia en provincias en estrecha vinculación con Francia como Navarra, de la que dependen obviamente figuraciones en la Rioja -sepulcros de San Bartolomé de Logroño. Menos numerosos son los ejemplos en Galicia -Fernán Pérez de Andrade -, y ya del siglo XV en Asturias -Juan Alonso y Aldonza González en Avilés.

Del siglo XIV existen bastantes ejemplares en provincias del norte. En la catedral de Vitoria se contabilizan el sepulcro de Vazterra II y el de un miembro de la familia Íñiguez, en Santa Cruz de Campezo, el de Fernán Ruiz de Gaona, el de un clérigo y en la parroquia de San Pedro el sepulcro de un Álava. El bachiller Oñate en San Miguel tiene un angelito, habiéndose perdido indudablemente el compañero ${ }^{113}$

En Álava aparece dicho tema en personajes no relacionados con la realeza, en iglesias de Vitoria y otros lugares. No se ha adoptado en cambio en Quejana, sin duda por ser encargo a otro taller, en este caso el toledano de Ferrand González. Llamo la atención sobre el hecho de que los reyes de la capilla de Reyes Nuevos, del mismo taller, alguno incluso firmado, están custodiados por ángeles, como la reina Beatriz

\footnotetext{
112 A. MusSAT, "Le chevalier et son double: ...", cit. p. 146

${ }^{113}$ Ma L. LAHOZ, Escultura funeraria gótica en Álava, Vitoria, 1996, pp. 49-223.
} 
de Portugal, esposa de Juan I, en el convento de Sancti Spiritus, en Toro ${ }^{114}$. En cuanto a su función, está vinculada a la liturgia, como ya se ha indicado. Así pues, creo que carecen de sentido las referencias al angelus bonus que se han invocado. Su asociación a la liturgia se colige del propio texto del canto In paradisum donde se explicita: " $A l$ paraíso te lleven los ángeles, I a tu llegada te reciban los mártires / y te introduzcan en la ciudad santa de Jerusalén"115.

Los yacentes se acompañan frecuentemente de animales, generalmente perros, de diversas razas, símbolo de la fidelidad o referencia a la caza, cuando se trata de poner en evidencia la profesión del noble sepultado. Junto a las damas y eclesiásticos se disponen perritos falderos como animales de compañía. Aparecen en número variado, uno dos, y hasta tres, como es el caso del sepulcro del abad Aparicio, ya citado ${ }^{116}$. Del mismo tipo son frecuentes varios ejemplares junto a yacentes de caballeros en Galicia. El lebrel ha sido venerado a la manera de un mártir por haber salvado a un niño de la mordedura de una serpiente ${ }^{117}$; su nombre le asocia a su aptitud para la caza de liebres. Esta razón le asocia a los caballeros junto al galgo. No faltan otros animales, cuyo simbolismo se relaciona con el mal y al pecado. La variedad animalística del sepulcro románico de la Magdalena, con leones, sirenas y dragones se reduce en los sepulcros góticos a animales de una sola especie. Llamo la atención a propósito del sepulcro de un obispo en la catedral de Astorga, de fecha temprana -hacia 1225-

\footnotetext{
${ }^{114}$ M. RuIz MALDONADO, "El sepulcro de doña Beatriz de Portugal en Sancti Spiritus (Toro)", Goya, 237 (1993), pp. 142-148.

115 .-D. SICARD, "La muerte del cristiano", La Iglesia en oración, cit. p. 809.

116 Á FRANCO MATA, Escultura gótica en el Museo Arqueológico Nacional, cit. pp. 100-102, n. 77.

${ }^{117}$ D. AleXANDRE-BidOn, La mort au Moyen Age XIIIe-XVIe siècle, cit. p. 270.
}

1250-, donde el prelado pisa un basilisco, emblema de la muerte ${ }^{118}$. Recuérdese que este animal fabuloso, según los Bestiarios medievales, tenía el poder de matar con su sola mirada. En la catedral de León varios yacentes de clérigos de distinto rango, enterrados en el claustro, se acompañan de leones -arcediano y maestro Facundo (+ $1250)$, canónigo Pedro Yáñez (+ 1258) (fig. $7)$, etc. ${ }^{119}$. La referencia bíblica de dichos animales y otros malignos es clara: "Caminarás sobre el escorpión y el basilisco, el león y el dragón", dice el Salmo 91 (90). La disposición de los animales antedichos a los pies de los yacentes significa su triunfo sobre la muerte y el pecado, es decir, de la muerte del cuerpo y del alma ${ }^{120}$.

Una notable serie de caballeros castellanos están sepultados con las piernas cruzadas, modalidad de origen inglés, sobre la que se han barajado diversas hipótesis, no analizadas suficientemente para nuestro país. Se trata de la modalidad denominada por E. Panofsky "movimiento de activación". Inglaterra es pródiga en este tipo iconográfico, que en el Somerset hace acto de presencia a mediados del siglo XIII y se le ha otorgado un carácter relacionado con la self-assurance de la nobleza media, que imponía progresivamente su presencia a los Comunes y a los $\operatorname{condados}^{121}$. J. W. Hurtig ha investigado la iconografía del caballero

118 Á FRANCO MATA, Escultura gótica en León..., cit. p. 421, láms. 299-302. Para este animal fantástico vid. I. MAlaXeCheVerría, Fauna fantástica de la Península Ibérica, San Sebastián 1991, pp. 99-105.

119 Á FRANCO MATA, Escultura gótica en León..., cit. láms. 266-268.

${ }^{120} \mathrm{P}$. CHIHAIA, Immortalité et décomposiotion dans l'art du moyen age, Madrid, 1988, p. 139.

${ }^{121}$ Ya hacia 1230 es el yacente de Juan sin Tierra, sin armadura, portador de la espada en la mano actitud que devendrá una norma en la escultura funeraria en Europa a lo largo del gótico. A. MUSSAT, “Le chevalier et son double: ..."cit. p. 151. 
yacente -the armored gisant- ${ }^{122}$, y sobre él vuelve H. A. Tummers, que lo amplía a otros estamentos sociales. Adelanta los primeros ejemplares a 1230-1240 -Shepton Mallet y Atherington- ${ }^{123}$. Incluye en dicha modalidad ejemplos de damas, que se datan a partir de 1300 en Cashel, Irlanda y ya en el siglo XIV en Howden Yorks. Los caballeros yacentes con las piernas cruzadas se representan sólo hasta mediados del siglo $\mathrm{XIV}$, en que desaparece el citado tipo ${ }^{124}$. Los brazos suelen adoptar tres posturas: a) en posición de descanso, b) sujetando la espada con la mano izquierda y la derecha sobre el pecho, alusión a la reverencia del caballero por los ideales de la fe cristiana y en consecuencia la fe en el más allá, y c) las manos en oración, actitud derivada de Francia $^{125}$. En las citadas variantes el crosslegget se mantiene sin especial sentido plástico, unas veces la pierna derecha sobre la izquierda y otras a la inversa, pero con predominio de la primera. Este grupo se diferencia del denominado lively martial attitu-

122 J. W. HURTIG, The armored gisant before 1400, New York University, tesis de doctorado, 1978.

${ }^{123}$ H. A. TUMMERS, Early Secular Effigies in England. The Thirteenth Century, Leiden, 1980, p. 107. Este autor propone prelación cronológica a las efigies de piedra de la región occidental a las de mármol de Purbeck (p. 111). Agradezco a mi buena amiga Almudena Cros el amable envío del texto.

${ }^{124}$ H. A. TUMMERs, Early Secular Effigies in England ..., cit. p. 114.

${ }^{125}$ H. A. TUMMERS, Early Secular Effigies in England ..., cit. p. 112-113. La efigie de William de Kerdiston, de hacia 1361, afecta una disposición muy particular; tendido sobre un lecho de guijarros, cruza sus brazos sobre el pecho. Tal vez se ha querido significar que murió en el campo de batalla, vid. catálogo exposición Age of Chivalry. Art in Plantagenet England 1200-1400, Londres, 1987 pp. 248-249, n. 135. Figuró en dicha exposición la placa de latón de Sir Williams de Setvans (ca. 1322) y una reproducción de la de Sir Robert de Bures (ca. 1331), ambos con las manos juntas en actitud de oración, idem. pp. 293-295, n. 234-235. de, exclusivo del Reino Unido, que afecta un carácter muy escultórico $^{126}$.

Dicha variedad dispositiva contrasta con la escasa de los ejemplares de caballeros castellanos. A diferencia de Inglaterra, no existen referencias de una posible existencia de yacentes de damas con las piernas cruzadas, ni de personajes civiles: la totalidad de yacentes pertenece a caballeros, la gran mayoría de los cuales se halla diseminada por la actual Castilla, en las provincias de Burgos, Palencia y Valladolid. Se conserva también algún ejemplar en Galicia, como el poeta P. Gómez Chariño, ya citado. Quizá ya rebasa el año 1300, y su yacija fue renovada hacia 1500 . Existen dudas si uno de los sepulcros de San Pedro de Rocas pertenece a esta modalidad $^{127}$.

El grupo de los primeros talleres de $\mathrm{Ca}$ rrión y el copioso conjunto diseminado por las provincias castellanas indicadas está relacionado con Antón Pérez de Carrión. El sepulcro del infante D. Felipe, junto al de su esposa en el citado monasterio templario de Villalcázar, encabeza la serie. Su disposición con las piernas cruzadas y la espada en alto, conforma una intencionalidad relacionada con la justicia, y constituye un auténtico acto de insolencia hacia la figura del rey Alfonso X, su hermano. Su deseo de exaltación del linaje se acentúa con los escudos enmarcando la representación de las exequias en los cuatro frentes de la urna, el caso más rico en la escultura gótica hispáni$\mathrm{ca}^{128}$. Otros ejemplares son el de D. Pedro

${ }^{126}$ H. A. TUMMERS, Early Secular Effigies in England ..., cit. pp. 114-117. La efigie de Robert Curthose, duque de Normandía, ca. 1250, perteneciente a esta modalidad, figuró en la exposición Age of Chivalry, vid. catálogo, p. 197, n. 2. Se le relaciona con el vigor del caballero de Cristo presto a colocarse a su servicio para el triunfo final.

127 S. MORALEJO ÁlVAREZ, Escultura gótica en Galicia, (1200-135), Santiago de Compostela, 1975, p. 28.

128 J. YARZA LUACES, “Despesas fazen los ommes de muchas guisas en soterrar los muertos", Fragmentos,
} 
Díaz de Castañeda, enterrado en el monasterio de Aguilar de Campoo ${ }^{129}$, un caballero desconocido de la familia Manrique de Lara, en la colegiata de la misma localidad, don Pedro Fernández Manrique y Zúñiga, sepultado en Palacios de Benaver (Burgos) ${ }^{130}$, caballeros sepultados en los monasterios vallisoletanos de Matallana, actualmente en el Museu Nacional d'Art de Catalunya ${ }^{131}$, y Palazuelos ${ }^{132}$, y un sepulcro en la colegiata de Santa María la Mayor de Valladolid ${ }^{133}$ Otros ejemplares se contabilizan fuera de su contexto, habiéndose perdido la referencia de su ubicación original ${ }^{134}$.

Los sepulcros con yacente del tipo en análisis han sido realizados tanto en piedra como en madera, éstos últimos en estado de conservación bastante deficiente. El grupo realizado en piedra afecta unos caracteres tipológicos muy definidos: el yacente, tanto con las piernas rectas como cruzadas constituye una unidad con la propia cubierta. El personaje está excavado sobre aquél y se cobija en una estructura arquitectónica rematada en arco apuntado. Está ataviado

2, 1985, pp. 4-19, recogido en Formas artísticas de lo imaginario, cit. pp. 280-281.

${ }^{129}$ J. L. HERNANDO GARRIDO, "Algunas notas sobre los sepulcros de Aguilar de Campoo: ...", cit. pp. 90-91.

130 Á. VeGUÉ Y GOLDONI, “Las estatuas tumulares de Palacios de Benaver (Contribución al estudio de la escultura funeraria medieval en Castilla)", Boletín de la Sociedad Española de Excursiones, 25-26 (1917-1918); M. RUIZ MALDONADO, “Escultura funeraria en Burgos...”, cit. pp. 82-83, fig. en p.116.

${ }^{131}$ En número de cinco, cfr. C. J. ARA GIL, Escultura gótica en Valladolid y su provincia, cit. pp. 48-51; Prefiguración del Museu Nacional d'Art de Catalunya, Barcelona, 1992, pp. 213-215

${ }^{132}$ C. J. ARA GIL, Escultura gótica en Valladolid y su provincia, pp. 36-41.

${ }^{133}$ C. J. ARA GIL, Escultura gótica en Valladolid y su provincia, cit. pp. 58-59.

${ }^{134}$ Ejemplar del Museo Marès de Barcelona, estudiado por F. ESPAÑOl BERTRÁN, "Coberta de sarcòfag", en F. ESPAÑOL BERTRÁN y J. YARZA LUACES (eds.) Fons del Museu Frederic Marès. Catàleg d'escultura $i$ pintura medievals/1, Barcelona, 1991, p. 252, n. 204 como corresponde a su estatus social de caballero, sostiene la espada con la mano izquierda y la derecha sujeta el cordón del manto, siguiendo el modelo inglés correspondiente al grupo b. Ocasionalmente recoge los pliegues del manto, como en la yacente de madera de Pedro González Manrique. A diferencia de los modelos británicos, los yacentes castellanos sostienen generalmente un halcón, símbolo de uno de los deportes de la nobleza, la cetrería, junto al de la montería. De hecho, desde el punto de vista social, dicho deporte era considerado como un privilegio. Diversos tratados sobre aquélla avalan dicha concepción; sirva de ejemplo para nuestro país el Libro de la Montería del Rey de Castilla Alfonso $X I^{135}$-.

En cuanto al simbolismo de las piernas cruzadas, sobre el que se han emitido diversas y a veces pintorescas hipótesis, recogidas y criticadas por Tummers ${ }^{136}$, parece fuera de duda, que no sirven las relacionadas ni con los caballeros templarios, $\mathrm{ni}$ con los cruzados. Más bien parece que debe de considerarse producto de una classconscious, de una clase social cada día más consciente de sus distinciones de $\operatorname{tal}^{137}$. Cualidad de arrogancia y engreimiento ha visto J. Yarza en la figura yacente del Infante don Felipe ${ }^{138}$ (figs. 8-9), lo que parece

-

135 Estudio preliminar de M. LÓPEz SERRANO, Madrid, 1969. Para Francia véase los tratados de Le livre du roi Modus et la royne Ratio, de autor anónimo, y Le miroir de Phoebus des déduits de la chasse des bêtes sauvages et des oiseaux de proye, de Gaston Phoebus, Señor de Béarn, en Histoire de France (ed. Larousse), p. 276. citado por P. CHIAIA, Immortalité et décomposition dans l'art du Moyen Age, Madrid, 1988,. p. 17.

${ }^{136}$ H. A. TUMMERS, Early Secular Effigies in England ..., cit pp. 117-125. Algunas opiniones ya fueron recogidas por la crítica española, así Carderera y F. Antón entre otros, y autores extranjeros que han estudiado el arte hispánico, como Bertaux.

${ }^{137}$ H. A. TUMMERS, Early Secular Effigies in England ..., cit. pp. 124-126.

${ }^{138}$ J. YARZA LUACES, Joaquín "Despesas fazen los ommes de muchas guisas en soterrar los muertos", cit., 
justificarse por la singularidad de la espada en alto, excepcional en el grupo. En cuanto al resto pienso que hay que relacionar la postura de las piernas cruzadas con unas señas de identidad como en los caballeros ingleses.

La incidencia del gótico castellano en Andalucía llegó con notable retraso. A diferencia de ambas Castillas, las tierras recién conquistadas, imbuidas del arte islámico, no adoptan la estatua yacente hasta el siglo XIV. La primera yacente, no de bulto, sino en metal, se remonta a la centuria anterior; se trata de la lauda de Juan de San Juan, caballero conquistador de Sevilla, que dotó la capilla de Santa Cruz, de la catedral de Sevilla en pleno siglo XIII. Por lo que respecta a bultos, no tenemos constancia de su existencia antes de 1330. De no considerarse "enterramiento de bulto que ella [María Alonso Coronel, esposa de Guzmán el Bueno], mandó allí [monasterio de Santiponce] fazer ocho años avía" [encargado en 1322], pero del que nada se conserva ${ }^{139}$, significarían una primicia las yacentes de dos descendientes del bravo caudillo, sepultados en el monasterio de San Isidoro del Campo en Santiponce, Juan Alonso Pérez de Guzmán [1351] y Bernardino de Zúñiga y Guzmán,

pp. 4-19, recogido en Formas artísticas de lo imaginario, cit, pp. 260-292.

${ }^{139}$ J. MARTÍNEZ DE AGUIRRE, “La primera escultura funeraria gótica en Sevilla: la capilla real y el sepulcro de Guzmán el Bueno (1248-1320)", Archivo Español de Arte, 270 (1995), pp. 111-129. Incluso, como advierte el autor, la palabra "bulto" frecuentemente en el siglo XIV hace referencia a una figura, una estatua, aunque en otras ocasiones se refiere a un sepulcro tumular. En este caso es presumible que no se tratara de un bulto funerario, considerando que Guzmán el Bueno proyectó su sepulcro en un espacio exclusivo en la nave de la iglesia; su familia tuvo que construir una nave aledaña para enterramiento de otros miembros de la familia. que conocemos a través de un dibujo conservado en el Archivo Central de Alcalá ${ }^{140}$.

Los sepulcros dobles, con sendos yacentes, son bastante frecuentes en Francia $^{141}$, excepcionales en Italia ${ }^{142}, y$ relativamente abundantes en España ${ }^{143}$. Se incluyen en este apartado los sepulcros que acogen a dos hermanos, a un matrimonio, un padre y un hijo. A esta modalidad responde el monumento de López de Ayala, en el monasterio de Quejana (Alava) ${ }^{144}$. También debía de responder a la misma el sepulcro con los yacentes de Juan González y doña Mayor, en Celada del Camino (Burgos). Otra variante es la del mismo yacente en dos actitudes, como es el caso del sepulcro tardío de la reina Beatriz de Portugal (+ 1430 ó 1431), figurada como reina y con hábito de dominica ya citado ${ }^{145}$.

En cuanto a materiales, se utilizaron distintos, el más comúnmente la piedra caliza, y en menor medida el mármol y el alabastro. No faltan los ejemplares en madera, cuyo espacio geográfico se detecta en

${ }^{140}$ Reproducido en J. Ma LUZÓN NOGUÉ, Sevilla la Vieja. Un paseo histórico por las ruinas de Itálica, Sevilla, 1999 , p. 70.

${ }^{141}$ A. MUSSAT, "Le chevalier et son double:...". cit. pp. $138-154$.

142 J. GARDNER, "A double tomb in Montefiore dell'Aso and Cardinal Gentile", Acta Historiae, 25 (1979), pp. 15-25.

${ }^{143}$ No analizo aquí los ejemplares del área catalana, sobre la que remito a F. ESPAÑOL BERTRÁN, Sicut ut decet. Sepulcro y espacio funerario en la Cataluña bajomedieval, Ante la muerte. Actitudes, espacios y formas en la España medieval, eds. J. Aurell y J. PAVÓN, Pamplona, 2002, pp. 95-156.

${ }^{144}$ S. de SILVA Y VERÁSTEGUI, , "Las empresas artísticas del Canciller Pedro López de Ayala", Vitoria en la Edad Media, Vitoria, 1982, pp. 761-777; L. LAHOZ, "La capilla funeraria del canciller Ayala. Sus relaciones con Italia", Boletín del Museo Instituto "Camón Aznar", 53 (1993), pp. 71-112; M ${ }^{\mathrm{a}}$ L. LAHOZ, Escultura funeraria gótica en Álava, Vitoria, 1996, pp. 155-186.

${ }^{145}$ M. RuIz MALDONADO, "El sepulcro de Doña Beatriz de Portugal en Sancti Spiritus (Toro)", cit. pp. 142-148. 
Burgos, Palencia y se extiende hasta la Liébana. La yacente de Santo Toribio, bastante maltrecho, en el monasterio de su nombre responde a dicha modalidad ${ }^{146}$. De alabastro son los sepulcros de los monarcas enterrados en la capilla de Reyes Nuevos, de la catedral de Toledo ${ }^{147}$, así como los de altos dignatarios de la Iglesia, como el Cardenal Gil de Albornoz y el arzobispo Pedro Tenorio y otros salidos del taller de Ferrand González ${ }^{148}$, tal el de Pedro Suárez de Tole$\mathrm{do}^{149}$.

A través de las citadas indicaciones sobre los destinatarios, se observa que el alabastro no es privativo de los reyes, por más que ellos lo adopten frecuentemente, constando como el caso más ostentoso el doble sepulcro de Juan II e Isabel de Portugal en la cartuja de Miraflores, obra excelsa de Gil de Siloe. Se trata del gusto de determinados talleres, como en el presente caso del de Ferrand González el toledano, cuya estela llega hasta puntos tan distantes de la geografía española como Álava y Sevilla.

El grupo de sepulcros de madera, realizados en la provincia de Burgos, con alguna proyección en provincias vecinas constituye un conjunto especialmente nota-

${ }^{146}$ Reproducido en J. GONZÁLEZ ECHEGARAY, “El ambiente lebaniego de Beato", J. YARZA LUACES, El Beato de Liébana. Manuscritos iluminados, Barcelona, 1998, p. 23. El autor data la yacente entre fines del siglo XIII y comienzos del XIV. Los rasgos estilísticos abonan por su datación en el siglo XIV

${ }^{147} \mathrm{~T}$ PÉREZ Higuera, "Los sepulcros de Reyes Nuevos", cit. Pp. 131-139.

${ }^{148}$ T PÉREZ Higuera, "Ferrand Gonzalez y los sepulcros del taller toledano (1385-1410)", Boletín del Seminario de Estudios de Arte y Arqueología, 44 (1978), pp. 129-139. Vid. también M. CENDÓN, Un obispo de Lugo en Santa Clara de Toledo: el sepulcro de Fray Juan Enríquez", Archivo Español de Arte, 279 (1997), pp. 302-310.

149 Á FrANCO MATA, Ángela, “El sepulcro de don Pedro Suárez III (s. XIV) y el taller toledano de Ferrad Gonzalez", cit. pp. 87-100, donde se alude a los yacentes y atuendo de los distintos personajes de los sepulcros tallados en el taller de Ferrand González ble, tanto por el material como por las peculiaridades iconográficas. Analizados los pertenecientes a varias familias nobles hace unos años por M. Ruiz Maldonado ${ }^{150}$, han llegado a nosotros en mejores o peores condiciones de conservación los de Día Sánchez de Rojas (+1349), y Sancho de Rojas (+ $1367)$, enterrados en el monasterio de Vileña y actualmente en Villarcayo, un "matrimonio", tres yacentes sepultados en Palacios de Benaver, actualmente en el Museo de Burgos. Parece ser que corresponde a Garci Fernández Manrique, su esposa doña Teresa Zúñiga y el hijo de ambos muerto joven, Pedro Fernández Manrique. En San Juan de Agüero estuvo sepultado Pedro González de Agüero, trasladado a Santillana del Mar. Cinco estatuas de nobles personajes, dos caballeros, dos damas y un clérigo, se hallan actualmente en el Museo de Burgos. Llamo la atención sobre el hecho de que aparecen generalmente con los ojos cerrados, salvo el de caballero de Vileña, tal vez Ferrand González de Rojas, y el de González de Agüero, que los tienen abiertos. Ambos sostienen un halcón, ocupación típicamente nobiliaria en tiempo de paz. Alguno ha emigrado a Estados Unidos, como es el caso del yacente de don Diego García de Villamayor, derivación iconográfica de una figura en pie; datado en el último cuarto del siglo XIII, se conserva actualmente en el Fogg Art Museum de Cambridge (MA) ${ }^{151}$.

La madera ya fue utilizada con anterioridad en la escultura funeraria de Ingla-

\footnotetext{
${ }^{150}$ M. RUIZ MALDONADO, “Escultura funeraria en Burgos:..., cit. pp. 45-126.

${ }^{151}$ F. D. DEKNATEL, "A Spanish Sculpture of the Thirteenth Century", FAM Bulletin, VI/2 (1937), pp. 3438; D[orothy] G[illerman], en Dorothy Gillerman (ed.), "Tomb Effigy of Don Diego Garcia de Villamayor", Gothic Sculpture in America. I. The New England Museums, Nueva York/Londres, 1989, pp. 174-175.
} 
terra y en Francia ${ }^{152}$. Concretamente en la abadía de Fontevraud A. ErlandeBrandenburg en su reciente estudio sobre "Le gisant d'Isabelle d'Angoulême" ha expuesto algunos conceptos dignos de mención $^{153}$. A la pregunta formulada por diversos investigadores de porqué este material para un personaje importante, se ha respondido que se trata de un recurso de orden económico, pues los altos personajes elegían materiales más nobles, como bronce, cobre esmaltado o la piedra. Sin embargo en Inglaterra la madera era considerada como material noble, como se deduce del testimonio de Robert Curthose a propósito de la yacente en madera mandada tallar para su madre por el rey Enrique III. El encargante pidió al artista inspirarse en la yacente de Leonor de Aquitania, y una vez tallada, ordenó trasladarla a Fontevraud, asistiendo él a la ceremonia de la traslación y colocación en su lugar. Robert Curthose, hijo de Guillermo el Conquistador, que, como es sabido, terminó sus días prisionero en el castillo de Cardiff, fue enterrado en la sala capitular, en el santuario de Gloucester, y transferido hacia 1250 a la catedral. El estilo de la yacente es similar a la de Isabel de Angulema y análogo el material. A la luz de dichos postulados, podría proponerse una determinada justificación para los yacentes hispanos. Quizá deba interpretarse como una modalidad paralela a los enterramientos en piedra, motivada tal vez por tratarse de un material frecuente en la zona.

Al contrario que en Italia, la escultura funeraria gótica española no es muy conspicua en la figuración de las Virtudes, teologales y cardinales. Sólo escasos monumentos sepulcrales están decorados con

\footnotetext{
${ }^{152}$ X. BARRAL I ALTET, "Tombeaux en bois et hiérarchisation sociale des commandes", X. BARRAL I ALTET (ed.), Artistes, Artisans et production artistique au Moyen Age, Rennes, 1983, pp. 153-155.

153 A. ERLANDE-BrANDENBURG, "Le gisant d'Isabelle d'Angoulême", cit. pp. 129-133.
}

dicha temática. Dejando aparte la referencia a la caridad interpretada como elemosina en sepulcros del siglo XIII -don Rodrigo II Álvarez, don Martín II Rodríguez, don Diego Ramírez de Guzmán (s. XIV), en la catedral de León-, me interesa aludir a las Virtudes en su conjunto. No cabe duda que dicho tema iconográfico proviene de Italia vía Toledo ${ }^{154}$. Ha sido Lucía Lahoz quien ha llamado la atención sobre dicho tema iconográfico en el conjunto sepulcral de don Pedro López de Ayala y su esposa doña Leonor de Guzmán, en su capilla funeraria del monasterio de Quejana (Álava), pertenecientes al citado taller toledano de Ferrand González. Aunque no siempre ha sido posible su identificación precisa, algunas de ellas, provistas de atributos ya codificados, son claramente identificables.

El gran creador de este tema iconográfico, como de tantos otros, es Giovanni Pisano, quien dispuso a las Virtudes como sustentantes del monumento sepulcral de Margarita de Brabante, esposa de Enrique VII, sepultada en San Francisco de Géno$\mathrm{va}^{155}$. Este memorable sepulcro, desgraciadamente muy destruido y fragmentado, sirvió de pauta para otros monumentos sepulcrales de sus discípulos Tino di Camaíno y Giovanni di Balduccio, difusores del mismo tipo. A la grandiosidad de las Virtudes sustentantes del sepulcro de personajes impregnados de sacralidad, sucede su inclusión con mucha mayor modestia en los sepulcros reseñados ${ }^{156}$.

-

154 Á. FRANCO MATA, “Arte y Literatura. El monumento sepulcral de Margarita de Brabante. Iconografía y significación de yacentes femeninos reales en la Baja Edad Media" Actas del I Congreso de Ephialte, Instituto de Estudios Iconográficos, Vitoria-Gasteiz, Lecturas de Historia del Arte, II, 1990, pp. 24-44.

155 M. SEIDEL, "Le Virtu”, Giovanni Pisano a Genova, catálogo exposición, Génova, 1987, pp. 75-119.

${ }^{156} \mathrm{M}^{\mathrm{a}} \mathrm{L}$. LAHOZ, Escultura funeraria gótica en Álava, cit. 
Bibliografía por orden cronológico.

V. CARDERERA Y SOLANO, Iconografía española. Colección de retratos, estatuas, mausoleos y demás monumentos inéditos de reyes, reinas, grandes capitanes, escritores, etc., desde el siglo XI hasta el XVII, Madrid, 1855-1864, 2 vols.

Á. Vegué Y GOLDONI, “Las estatuas tumulares de Palacios de Benaver (Contribución al estudio de la escultura funeraria medieval en Castilla)", Boletín de la Sociedad Española de Excursiones, 25-26 (1917-1918).

M. Martínez Burgos, y J. L. de Monteverde, "Los sepulcros de madera policromada del Monasterio de Vileña", en Homenaje a Mélida. Anuario del Cuerpo Facultativo de Archiveros, Bibliotecarios y Arqueólogos, Madrid, 1935, p. 183.

Museo de Vileña (Burgos), Memorias de los Museos Arqueológicos Provinciales 1943, Extractos, Madrid, 1944, vol. IV, pp. 202-203.

R. DEL ARCO, Sepulcros de la Casa Real de Castilla, Madrid, 1954.

E. PANOFSKY, Tomb Sculpture. Its Changing Aspects Ancient Egypt to Bernini, Londres, 1964, reed. Nueva York, 1992.

M. Gómez Moreno, Catálogo Monumental de España. Provincia de Salamanca, Madrid, 1967, 2 vols.

S. Moralejo Álvarez, Escultura gótica en Galicia (1200-1350), Santiago de Compostela, 1975.

K. BAUCH, Das mittelalterliche Grabbild. Figürliche Grabmäler des 11. Bis 15 Jahrhunderts in Europa, Berlín/Nueva York, 1976.

C. J. ARA GIL, Escultura gótica en Valladolid y su provincia, Valladolid, 1977.

J. W. HuRTIG, The armored gisant before 1400, New York University, tesis de doct., 1978.

T. PÉrez Higuera, "Ferrand Gonzalez y los sepulcros del taller toledano (1385-1410)", Boletín del Seminario de Estudios de Arte y Arqueología, 44 (1978), pp. 129-139.

H. A. TUMMERS, Early Secular Effigies in England. The Thirteenth Century, Leiden, 1980.

S. DE SILVA Y Verástegui, "Las empresas artísticas del Canciller Pedro López de Ayala", Vitoria en la Edad Media, Vitoria, 1982, pp. 761777.

X. BARRAL I ALteT,"Tombeaux en bois et hiérarchisation sociale des commandes", en Xavier Barral i Altet (ed.), Artistes, Artisans et production artistique au Moyen Age, Rennes, 1983, pp. 153-155.
Ma J. Gómez BÁRCenA, La Visitación y el Nacimiento en los sepulcros góticos burgaleses, Boletín de la Institución Fernán González, 199 (1982), pp. 307-316.

Ma J. Gómez BÁrCENA, La Anunciación en los sepulcros góticos burgaleses, Reales Sitios, 78, Madrid, 1983, pp. 65-72.

Mª J. GómEZ BÁRCENA, Escultura gótica funeraria en Burgos, Burgos, 1988.

Mª J. Gómez BÁRCENA, "El sepulcro gótico en la ciudad de Burgos en la crisis del siglo XIV", en La ciudad de Burgos. Actas del Congreso de Historia de Burgos MC Aniversario de la fundación de la ciudad de Burgos 884-1984, Burgos, 1985, pp. 863-881.

M. Núñez Rodríguez, "Iconografía de humildad: el yacente de Sancho IV", Boletín del Museo Arqueológico Nacional, 3 (1985), pp. 169-175

El Panteón Real de las Huelgas de Burgos. Los enterramientos de los Reyes de León y de Castilla, Valladolid, 1988.

Á. Franco MatA, "Relaciones hispano-italianas de la escultura funeraria del siglo XIV", en M. NúÑEZ y E. PORTEla (eds.) La Idea y el Sentimiento de la Muerte en la Historia y en el Arte de la Edad Media, Santiago de Compostela, 1988, pp. 99-125.

Ma J. GÓMEz BÁRCENA, “La liturgia de los funerales y su repercusión en la escultura funeraria gótica en Castilla", en La Idea y el Sentimiento de la Muerte en la Historia y en el Arte de la Edad Media, Santiago de Compostela, 1988, pp. 31-50.

J.-P. GABORIT, "Sur un lit de parade" essai d'interpretation d'un motif funéraire, pp. La figuration des morts dans la chretienté médiévale jusqu'à la fin du premier quart du XIVe siècle, Fontevraud, 1988, pp 117-123.

J. L. Hernando GARRIDO, “Algunas notas sobre los sepulcros de Aguilar de Campoo: un grupo escultórico palentino de 1300", Boletín del Museo e Instituto "Camón Aznar", 37 (1989), pp. 90-91.

T. PÉrez Higuera, “Los sepulcros de Reyes Nuevos (Catedral de Toledo)" Tekné, 1 (1985), pp. 131-139

A. Mussat, "Le chevalier et son double: Naissance d'une image funéraire (XIIIe siècle)", La figuration des morts dans la chretienté médiévale jusqu'à la fin du premier quart du XIVe siècle, Fontevraud, 1988, pp. 138-154. 
M.-M. GAUTHIER, “Naissance du defunt a la vie eternelle: les tombeaux d'émaux de Limoges aux XIIe et XIIIe siécles", La figuration des morts dans la chretienté médiévale jusqu'à la fin $d u$ premier quart $d u$ XIVe siècle, Fontevraud, 1988, pp. 97-116.

Á. Franco MAtA, “El sepulcro de don Pedro Suárez III (s. XIV) y el taller toledano de Ferrad Gonzalez", Boletín del Museo Arqueológico Nacional, 9, (1991), pp. 87-100.

C. MAnso Porto, Arte gótico en Galicia: los Dominicos, La Coruña, 1993, 2 vols.

Á. Franco MATA, Escultura gótica en el Museo Arqueológico Nacional (1980), 2 $2^{\mathrm{a}}$ ed, Madrid, 1993.

L. LAHOZ, "La capilla funeraria del canciller Ayala. Sus relaciones con Italia", Boletín del Museo Instituto "Camón Aznar", 53 (1993), pp. 71-112.

R. SÁNCHEZ AMEIJEIRAS, “Un espectáculo urbano en la Castilla medieval: las honras fúnebres del caballero", El Rostro y el Discurso de la Fiesta, ed. M. NúÑEZ RodRíGUEZ, Santiago de Compostela, 1994, pp. 141-157.

M. Ruiz MaldonAdo, "Escultura funeraria en Burgos: los sepulcros de los Rojas, Celada y su círculo", Boletín del Museo e Instituto "Camón Aznar", 56 (1994), pp. 45-126.

M. Ruiz MALDONADO, “El sepulcro del arcediano Garci López. Catedral Vieja de Salamanca", en Estudios de Arte. Homenaje al Profesor Martín González, Valladolid, 1995, pp. 433-437.

L. LAHOZ, Escultura funeraria gótica en Álava, Vitoria, 1996.

L. MorgantI, La celebrazione degli 'Anniversari' e l'affermazione del concetto di Purgatorio nel XIII secolo: il monumento di Martín Rodríguez nella cattedrale di León e Lucas de Tuy, Arte medievale, X, (1996), pp. 99-122.

M. RuIZ MALDONADO, “Escultura funeraria del siglo XIII: los sepulcros de los López de
Haro", Boletín del Museo e Instituto "Camón Aznar", LXVI (1996), pp. 91-169.

A. ERLANDE-BRANDENBURG, "Le gisant d'Isabelle d'Angoulême", en Isabelle d'Angoulême, comtesse-reine et son temps (1186-1246), Actas del Coloquio celebrado en Lusignan 8-10 nov. 1996, Centre d'Études Súperieures de Civilisation Médiévale, 1999, pp. 129-133

M. CENDÓn FERnÁndeZ, “Un obispo de Lugo en Santa Clara de Toledo: el sepulcro de Fray Juan Enríquez", Archivo Español de Arte, 279 (1997), pp. 302-310.

Á. FRANCO MATA, Escultura gótica en León y provincia (1230-1530), León, 1998.

N. TORRES BALLESTEROS, “La muerte como aspecto de la vida cotidiana medieval: los sepulcros de Villasirga", Vida cotidiana en la España Medieval, actas del VI Curso de Cultura Medieval, Aguilar de Campoo, 1994, Aguilar de Campoo, 1998, pp. 427-456.

R. SÁNCHEZ AMEIJEIRAS, "Fundamenta and Monumenta" the XIII century episcopal pantheon of Leon Cathedral ", Memory and the Medieval Tomb, ed. E. VAlDEZ DEL AlAmo y C. Stamatis PEndergast, Cambridge, 2000, pp. 269-299.

C. García Álvarez, El laberinto del alma. Una interpretación de las enjutas de las capillas absidales de la Catedral de León, León, Universidad, 2003.

R. SÁNCHEZ AMEIJEIRAS, “Muy de coraçon rogava a Santa María: culpas irredentas y reivindicación política en Villasirga", Patrimonio artístico de Galicia y otros estudios. Homenaje a Serafin Moralejo, Santiago de Compostela, 2004, vol. III, pp. 237-248.

Á. FrAnCo MATA, Imagen del yacente en la Corona de Castilla (ss. XIII-XIV), Boletín del Museo Arqueológico Nacional (en prensa). 

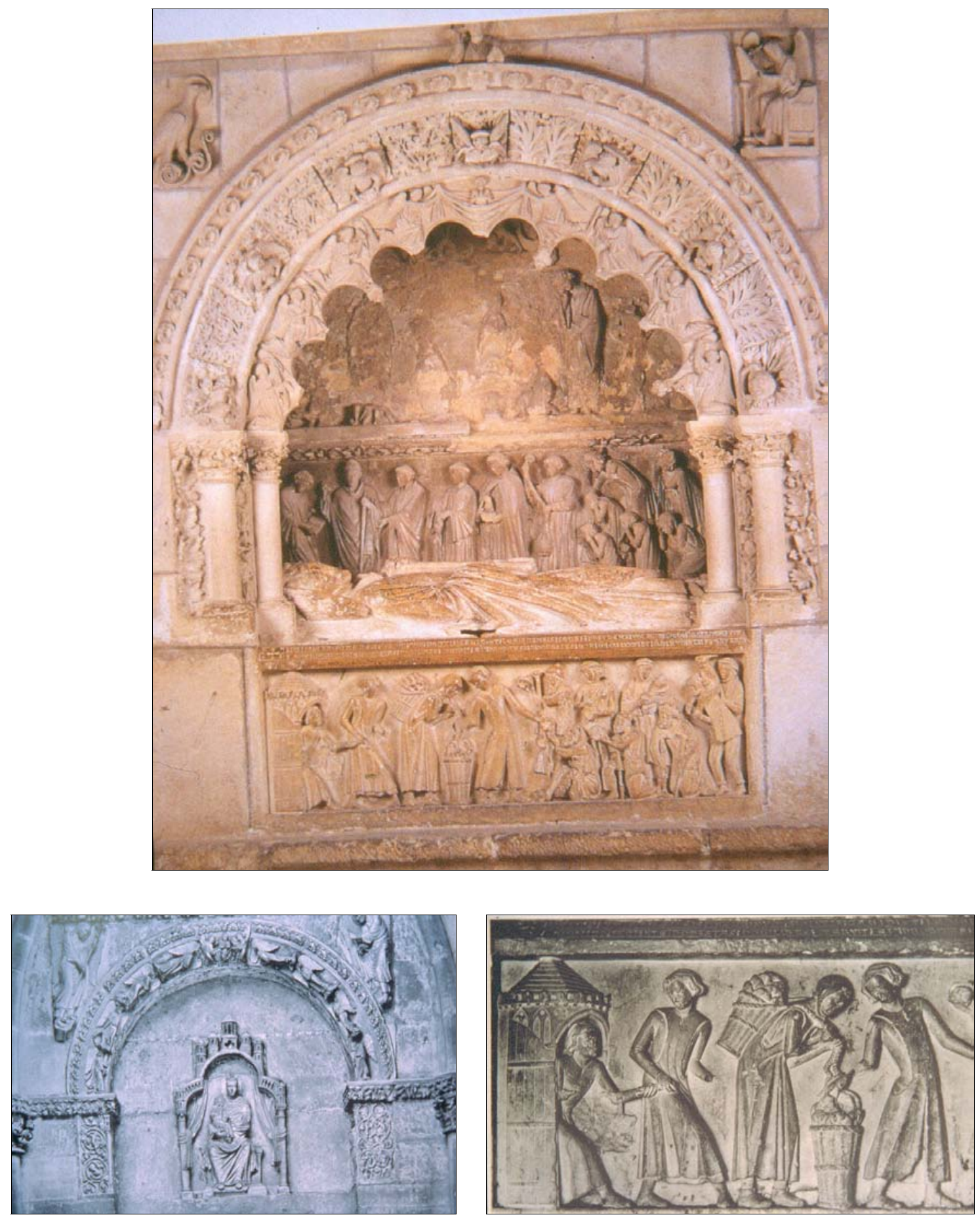

- Fig. 1. Sepulcro del obispo don Martín II Rodríguez (+ 1242), catedral de León. Hacia 12601265 (arriba centro)

- Fig. 2. Porte Romane, transformación del sepulcro de Henry de France (+ 1171), catedral de Reims (abajo izquierda)

- Fig. 3. Sepulcro del obispo don Martín Rodríguez(+ 1242), detalle, catedral de León. Hacia 1260-1265 (abajo derecha) 

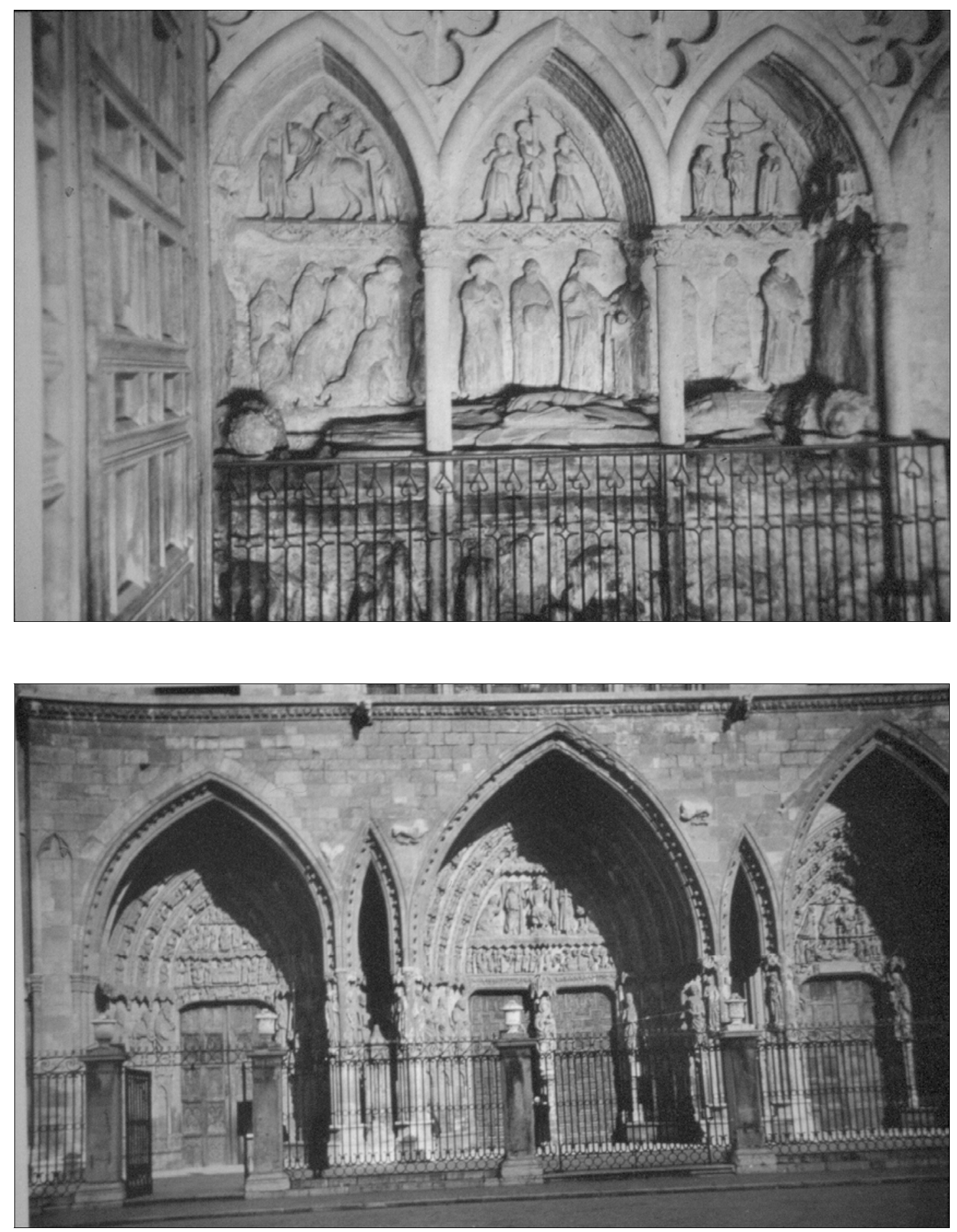

- Fig. 4. Sepulcro del obispo don Martín Fernández (+ 1289), catedral de León. Hacia 1289 (arriba centro)

- Fig. 5. Pórtico Occidental de la catedral de León. 1260-1280 (abajo centro) 

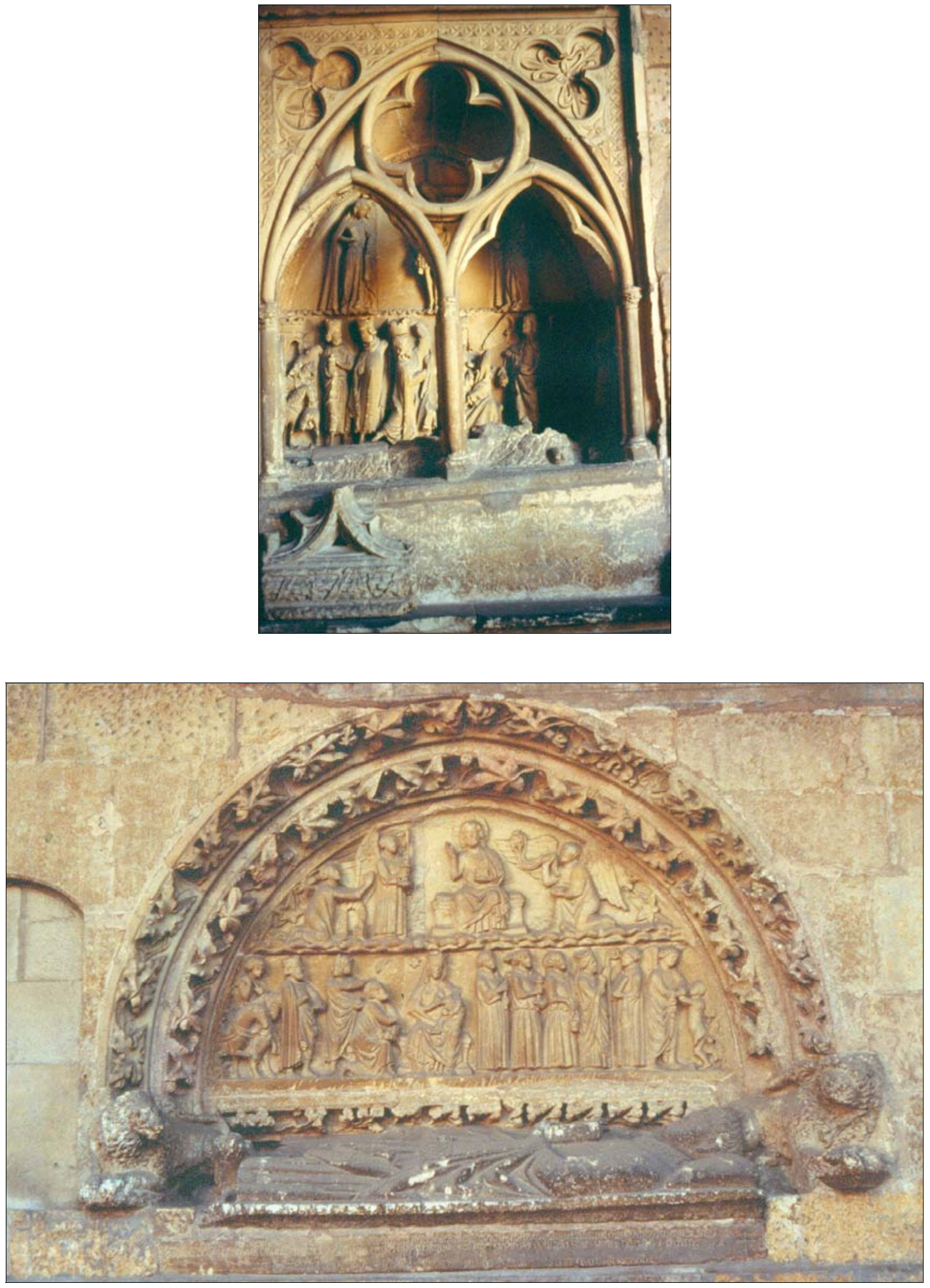

- Fig. 6. Sepulcro del deán don Martín Fernández, 1255-1260, claustro catedral de León (arriba centro)

- Fig. 7. Sepulcro de don Pedro Yáñez (+ 1258), claustro catedral de León. Antes de 1274 (abajo centro) 

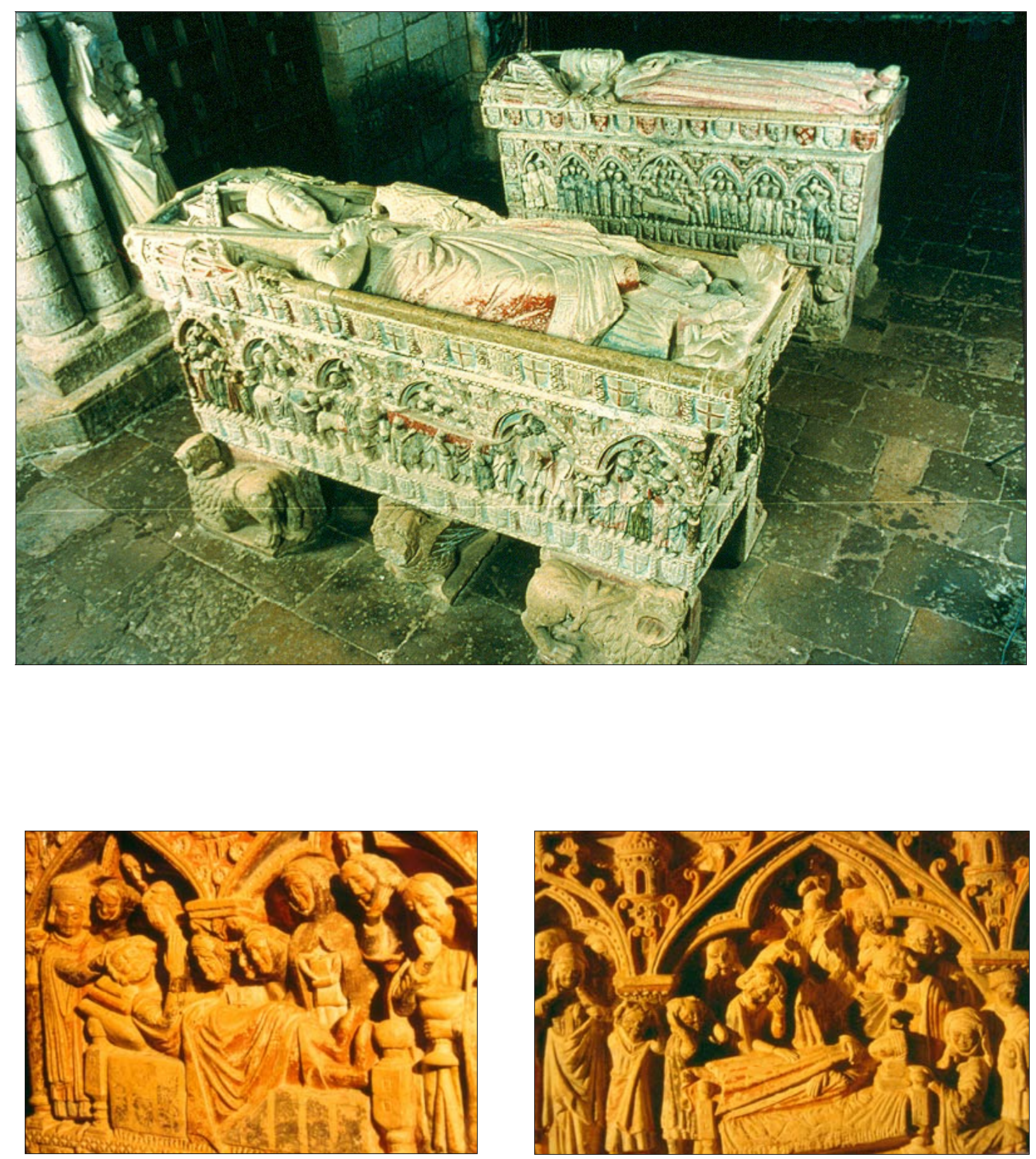

- Fig. 8. Sepulcros del infante don Felipe y su esposa doña Inés Téllez Girón, Villacázar de Sirga (Palencia) (arriba centro)

- Fig. 9. Sepulcro del infante don Felipe, detalle, Villacázar de Sirga (Palencia). Hacia 1274. (abajo izquierda)

- Fig. 10. Sepulcro doña Inés Téllez Girón, detalle, Villacázar de Sirga (Palencia). Hacia 1274 (abajo derecha) 

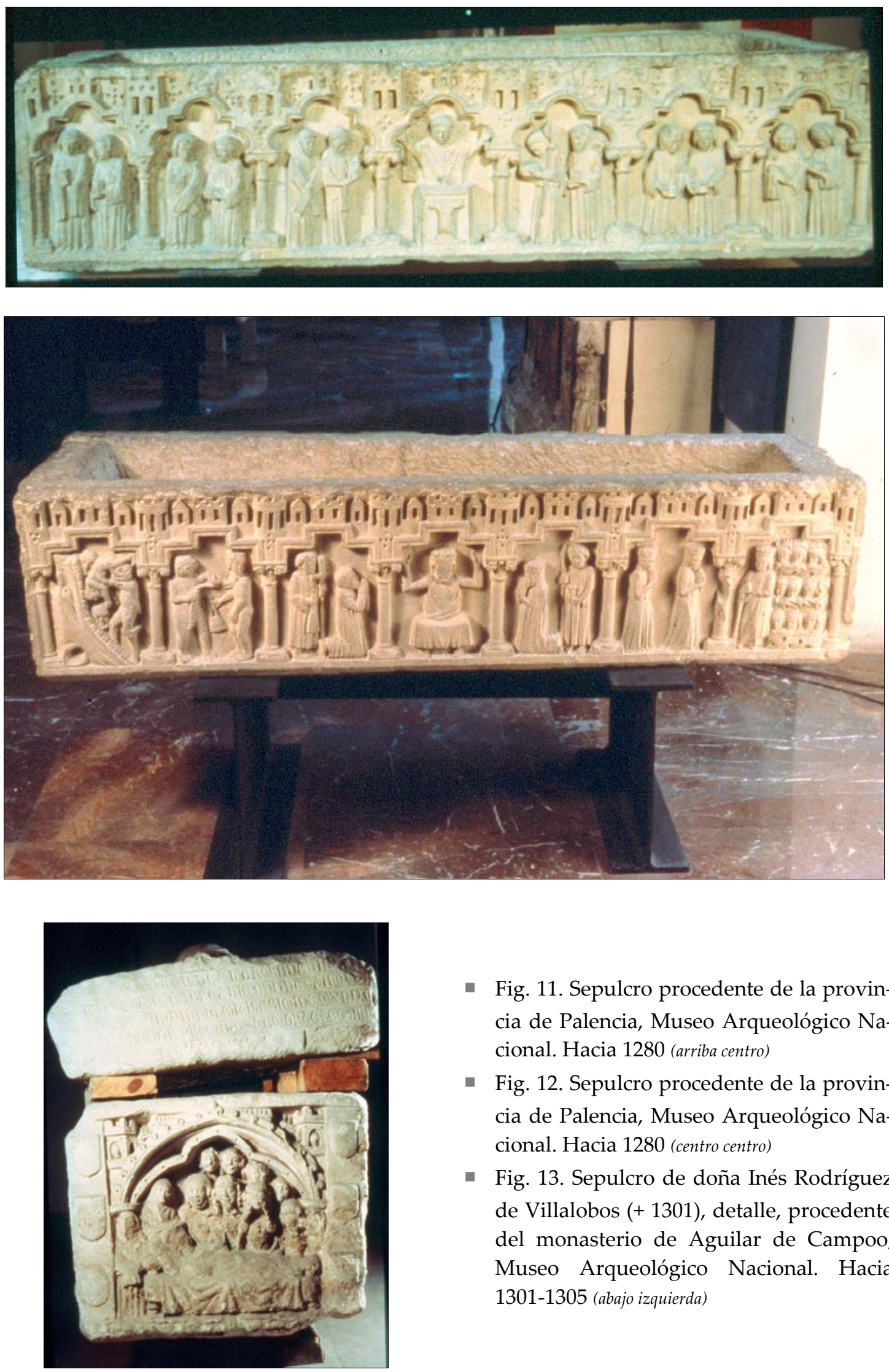

- Fig. 11. Sepulcro procedente de la provincia de Palencia, Museo Arqueológico Nacional. Hacia 1280 (arriba centro)

- Fig. 12. Sepulcro procedente de la provincia de Palencia, Museo Arqueológico Nacional. Hacia 1280 (centro centro)

- Fig. 13. Sepulcro de doña Inés Rodríguez de Villalobos (+ 1301), detalle, procedente del monasterio de Aguilar de Campoo, Museo Arqueológico Nacional. Hacia 1301-1305 (abajo izquierda) 

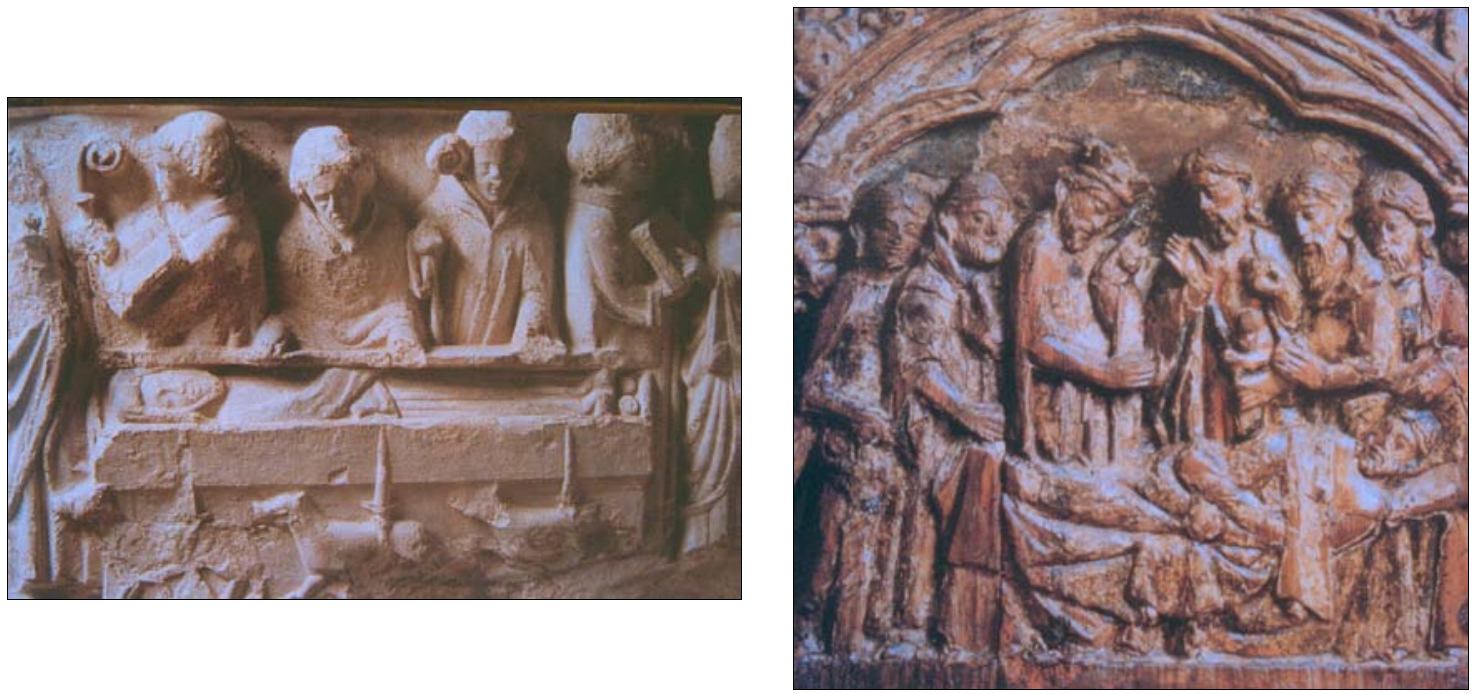

- Fig. 14. Sepulcro de doña Urraca López de Haro, detalle, monasterio de Vileña (Burgos), después de 1275 (arriba izquierda)

- Fig. 15. Sepulcro de don Sancho Sánchez de Rojas(Nájera, + 3 de abril de 1367), detalle, en origen en el monasterio de Vileña, y actualmente en Villarcayo (Burgos). Hacia 1367-1370 (arriba derecha) 